\title{
New evidence of an Ediacaran age for the Bambuí Group in southern São Francisco craton (eastern Brazil) from zircon U-Pb data and isotope chemostratigraphy
}

\author{
Gustavo Macedo Paula-Santos ${ }^{\mathrm{a}, *}$, Marly Babinski ${ }^{\mathrm{a}}$, Matheus Kuchenbecker ${ }^{\mathrm{b}}$, Sergio Caetano-Filho ${ }^{\mathrm{c}}$, \\ Ricardo Ivan Trindade ${ }^{\mathrm{d}}$, Antonio Carlos Pedrosa-Soares ${ }^{\mathrm{b}}$ \\ a Instituto de Geociências, Universidade de São Paulo, Rua do Lago, 562, Cidade Universitária, São Paulo, SP CEP: 05508-080, Brazil \\ b Instituto de Geociências-CPMTC, Universidade Federal de Minas Gerais, Av. Antônio Carlos, 6627, Campus Pampulha, Belo Horizonte, MG CEP: 31270-901, Brazil \\ c Instituto de Geociências e Ciências Exatas, Universidade Estadual Paulista, Av. 24A, Rio Claro, SP CEP: 13506-900, Brazil \\ d Instituto de Astronomia e Geofisica, Universidade de São Paulo, Rua do Matão, 1226, São Paulo, SP CEP: 05508-090, Brazil
}

\section{A R T I C L E I N F O}

\section{Article history:}

Received 13 December 2013

Received in revised form 16 June 2014

Accepted 28 July 2014

Available online 23 August 2014

Handling Editor: A.S. Collins

Keywords:

Bambuí Group

São Francisco craton

$\mathrm{U}-\mathrm{Pb}$ dating

$\mathrm{Sr}$ isotopes

\begin{abstract}
A B S T R A C T
Extensive carbonate-siliciclastic successions of the Bambuí Group, which overlie Neoproterozoic glaciogenic diamictites, cover most of the southern São Francisco craton (eastern Brazil). This group records sedimentation in a foreland setting related to the diachronic orogenic processes that formed the Brasília and Araçuaí marginal belts. The lowermost unit of the Bambuí Group, the Sete Lagoas Formation, comprises two shallowing-upward sequences of carbonate rocks with subordinated pelitic intercalations, overlying the glaciogenic diamictites in the southern São Francisco Craton. This study combines isotope chemostratigraphy $(\mathrm{C}, \mathrm{O}, \mathrm{Sr})$ and U-Pb dating of zircon detrital grains retrieved from marls of the Sete Lagoas Formation. The basal sequence comprises low organic matter limestones and dolostones with $\delta^{13} \mathrm{C}$ values around $0 \%$, positioned above cap carbonates dated at around $740 \mathrm{Ma}(\mathrm{Pb}-\mathrm{Pb}$ whole-rock isochron). The U-Pb ages obtained for this sequence show several age peaks between 1270-870 Ma and 625-550 Ma. The upper sequence includes dark limestones with $\delta^{13} \mathrm{C}$ values as high as $+10 \%$, best preserved ${ }^{87} \mathrm{Sr} /{ }^{86} \mathrm{Sr}$ ratios of around 0.7075 and $\mathrm{U}-\mathrm{Pb}$ ages ranging from $625 \mathrm{Ma}$ to $550 \mathrm{Ma}$. Our geochronological data suggest that the Araçuaí orogen is the main source of sediment for the Sete Lagoas Formation, and the youngest zircon population sets the maximum depositional age for its upper part at around $557 \mathrm{Ma}$. This suggests that the studied section of the Sete Lagoas Formation is not related to either the Sturtian or the Marinoan glacial events. Also, the ${ }^{87} \mathrm{Sr} /{ }^{86} \mathrm{Sr}$ ratios obtained from Sete Lagoas carbonates contrast with Sr evolution curves available in the literature, especially with those for the Ediacaran-Cambrian limit, when ratios higher than 0.7080 would be expected. The same discrepancy is reported for other Ediacaran carbonate successions, pointing to local disturbances in $\mathrm{Sr}$ composition of marine basins rather than global processes. Interbasinal correlations and blind dating based on isotope chemostratigraphy should proceed carefully, especially for Ediacaran marine deposits located on the inner parts of large palaeocontinental regions, such as those found in western Gondwana.
\end{abstract}

(c) 2014 International Association for Gondwana Research. Published by Elsevier B.V. All rights reserved.

\section{Introduction}

The São Francisco craton, together with its counterpart located in Africa, the Congo craton (Fig. 1), represents the stable part of one of the plates involved in the assembly process of western Gondwana, in the Neoproterozoic (Cordani et al., 2003). This long-lasting orogenic process, represented by the Brasiliano-Pan African event, formed diachronic mobile belts adjacent to those cratons, like the Araçuaí and Brasilia belts that, respectively, place the east and west limits of the São Francisco craton (Brito-Neves et al., 1999). Around the EdiacaranCambrian boundary, the São Francisco craton and related orogenic

\footnotetext{
* Corresponding author.

E-mail address: gustavomps@yahoo.com.br (G.M. Paula-Santos).
}

belts occupied a central place in the newborn western Gondwana (Trindade et al., 2006; Li et al., 2008). By that time, both the Araçuaí and Brasília belts have already been uplifted against the São Francisco craton, showing Neoproterozoic stratigraphic unit thrust onto the cratonic covers included in the Bambuí Group (Dardenne, 2000; Alkmim et al., 2006; Valeriano et al., 2008; Pedrosa-Soares et al., 2011a).

The Bambuí Group includes a thick (up to $1000 \mathrm{~m}$ ) carbonatesiliciclastic succession covering a large region of the southern São Francisco Craton, in eastern Brazil (Fig. 1). The lithostratigraphic subdivision of the Bambuí Group into five formations (namely the Sete Lagoas, Serra de Santa Helena, Lagoa do Jacaré, Serra da Saudade and Três Marias Formations) suggested by Dardenne (1978) is still the most accepted in the literature (e.g., Santos et al., 2000, 2004; Alvarenga et al., 2007; Babinski et al., 2007; Vieira et al., 2007; Sial et al., 2009; Babinski et al., 2012). 

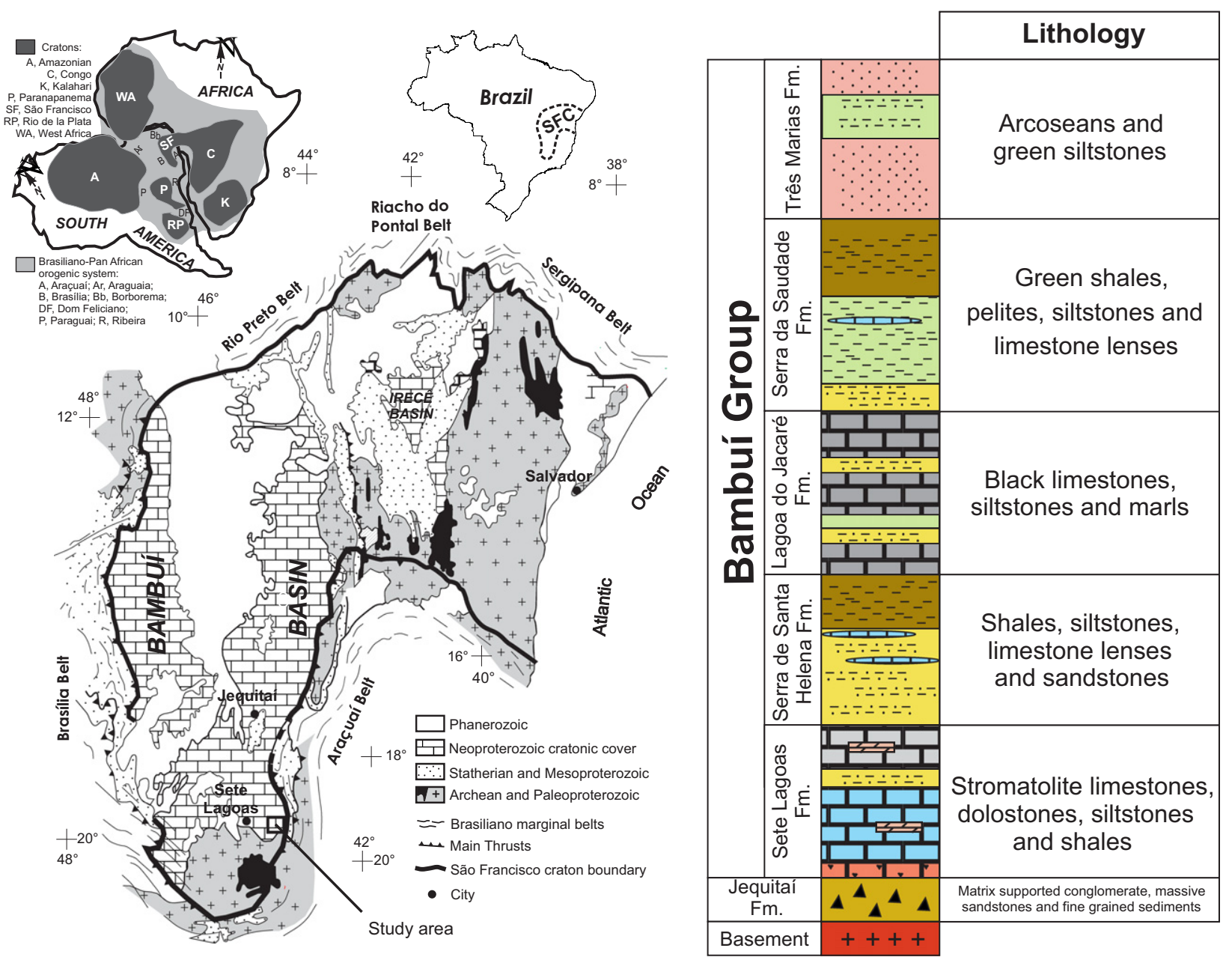

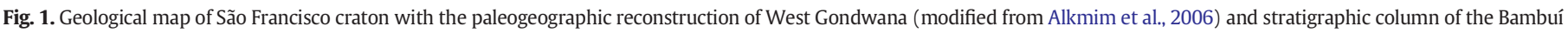
Group based on Dardenne (1978).

The Sete Lagoas Formation, the lowermost unit of the Bambuí Group, crops out close to basement highs in the southern part of the São Francisco craton (Fig. 1). This unit comprises two shallowing-upward sequences of carbonates with interbedded pelitic rocks (Vieira et al., 2007). The lower carbonates overlie glaciogenic diamictites and associated deposits correlated to the Jequitaí and Carrancas formations (Uhlein et al., 1999; Martins-Neto et al., 2001; Martins-Neto and Hercos, 2002; Vieira et al., 2007; Kuchenbecker et al., 2013). This stratigraphic framework established the Sete Lagoas Formation as one of the 'cap carbonate' successions deposited above glacial deposits that record Neoproterozoic extreme glacial events (Babinski et al., 2007; Vieira et al., 2007; Caxito et al., 2012). This is supported by the $\delta^{13} \mathrm{C}$ negative anomalies found within the base of the unit. Nevertheless, the sedimentary evolution, the age of the Sete Lagoas Formation and the glacial event which pre-dates the carbonate deposition have been themes of intense debate, mainly because of controversial arguments facing blind dating and absolute geochronological data.

Babinski et al. (2007) obtained a ${ }^{207} \mathrm{~Pb}-{ }^{206} \mathrm{~Pb}$ isochron age of $740 \pm 22 \mathrm{Ma}$ on the least altered samples of the basal cap carbonates and, therefore, considered the Sete Lagoas Formation as a post-Sturtian succession. Rodrigues (2008) and Pimentel et al. (2011) reported a maximum depositional age of $610 \mathrm{Ma}$ after dating, by the U-Pb method, detrital zircons retrieved from pelitic layers of the upper sequence of the Sete Lagoas Formation, and correlate it with post-Marinoan carbonate successions. Recently, the Ediacaran guide fossil Cloudina has been described in these carbonates (Warren et al., 2014), bringing more pieces to the Bambuí Group puzzle. A possible major unconformity between the lower and upper sequences of the Sete Lagoas Formation has been postulated, as such sequence boundary is characterized by an abrupt shift on the $\delta^{13} \mathrm{C}$ curve, from values around $0 \%$ o to values higher than $+6 \%$ (Santos et al., 2000; Vieira et al., 2007). However, no field evidence has been found. The geochronological data from older glacial units in the region do not help solve the puzzle, as their maximum depositional ages are around $900 \mathrm{Ma}$ (Buchwaldt et al., 1999; Pedrosa-Soares et al., 2000; Babinski et al., 2012).

The recently published $\mathrm{Sr}$ and $\mathrm{Ca}$ isotope data of the carbonates of the Sete Lagoas Formation led to the same uncertainty. Sr isotope chemostratigraphy has been successfully used to correlate carbonate successions, especially the Neoproterozoic ones that lack reliable biostratigraphic markers (Derry et al., 1992; Misi and Veizer, 1998; Walter et al., 2000; Alvarenga et al., 2004, 2008; Ovchinnikova et al., 2012; Li et al., 2013; Kusnetsov et al., 2013). The correlations are performed comparing the ${ }^{87} \mathrm{Sr} /{ }^{86} \mathrm{Sr}$ ratios of the least altered seawater precipitated carbonates to reference curves of the secular variations of the ${ }^{87} \mathrm{Sr} /{ }^{86} \mathrm{Sr}$ composition of ancient oceans (Veizer et al., 1989; Halverson et al., 2007). Such variations occur as three main sources deliver different $\mathrm{Sr}$ compositions in different proportions to the ocean, namely: i) the Sr runoff from continental weathering, ii) reworking of ancient carbonates on marine platforms, and iii) hydrothermal alteration of the oceanic crust (Palmer and Edmond, 1989). As the Sr residence time in oceans ( $2.4 \mathrm{Ma}$; Jones and Jenkyns, 2001$)$ is considerably higher than the ocean's mixing time $\left(10^{5}\right.$ years; Jacobsen and Kaufman, 1999), ${ }^{87} \mathrm{Sr} /{ }^{86} \mathrm{Sr}$ ratios of coeval marine carbonates are similar owing to the homogeneity of the $\mathrm{Sr}$ isotopic composition for a global ocean and 
marginal seas (Kusnetsov et al., 2012). Therefore, Sr chemostratigraphy may be useful for "blind dating" carbonate successions, as long as some caution is taken (Melezhik et al., 2001). But the effectiveness of the technique depends on the accuracy of the used reference curve, which is limited due to difficulties to obtain absolute ages on carbonate successions. Moreover, the same ${ }^{87} \mathrm{Sr} /{ }^{86} \mathrm{Sr}$ ratio can be representative of different periods in the ocean isotopic evolution. That seems to be the case in the Bambui Group. ${ }^{87} \mathrm{Sr} /{ }^{86} \mathrm{Sr}$ ratios around $0.7074-0.7075$ are commonly reported for the Sete Lagoas Formation (Babinski et al., 2007; Misi et al., 2007; Kuchenbecker, 2011). Although Caxito et al. (2012) considered these ratios typical of post-Marinoan carbonates by using the Sr evolution curve of Halverson et al. (2010), the same ratios

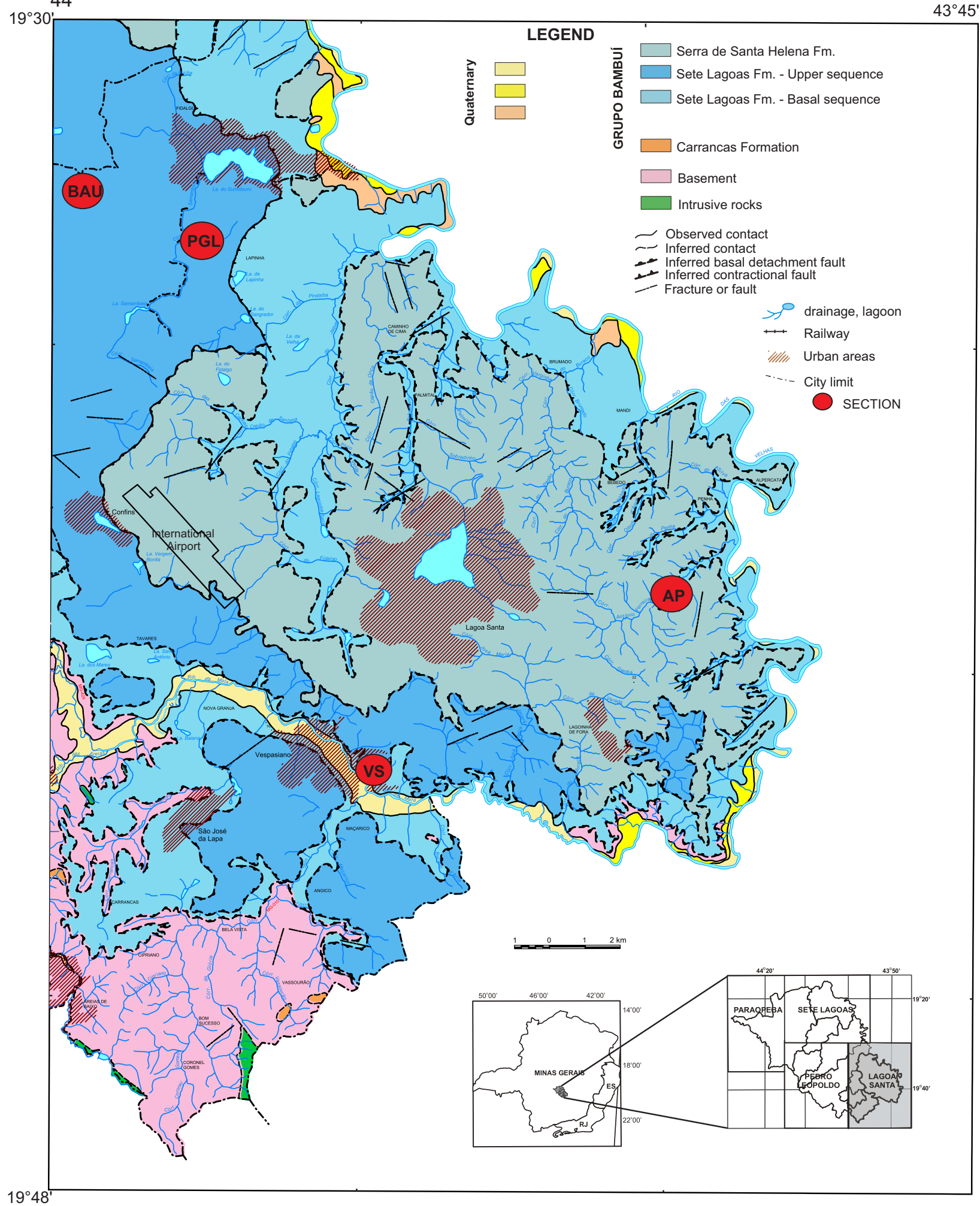

Fig. 2. Geological map of the studied area with the location of the described sections. Modified from Projeto VIDA (2003). 


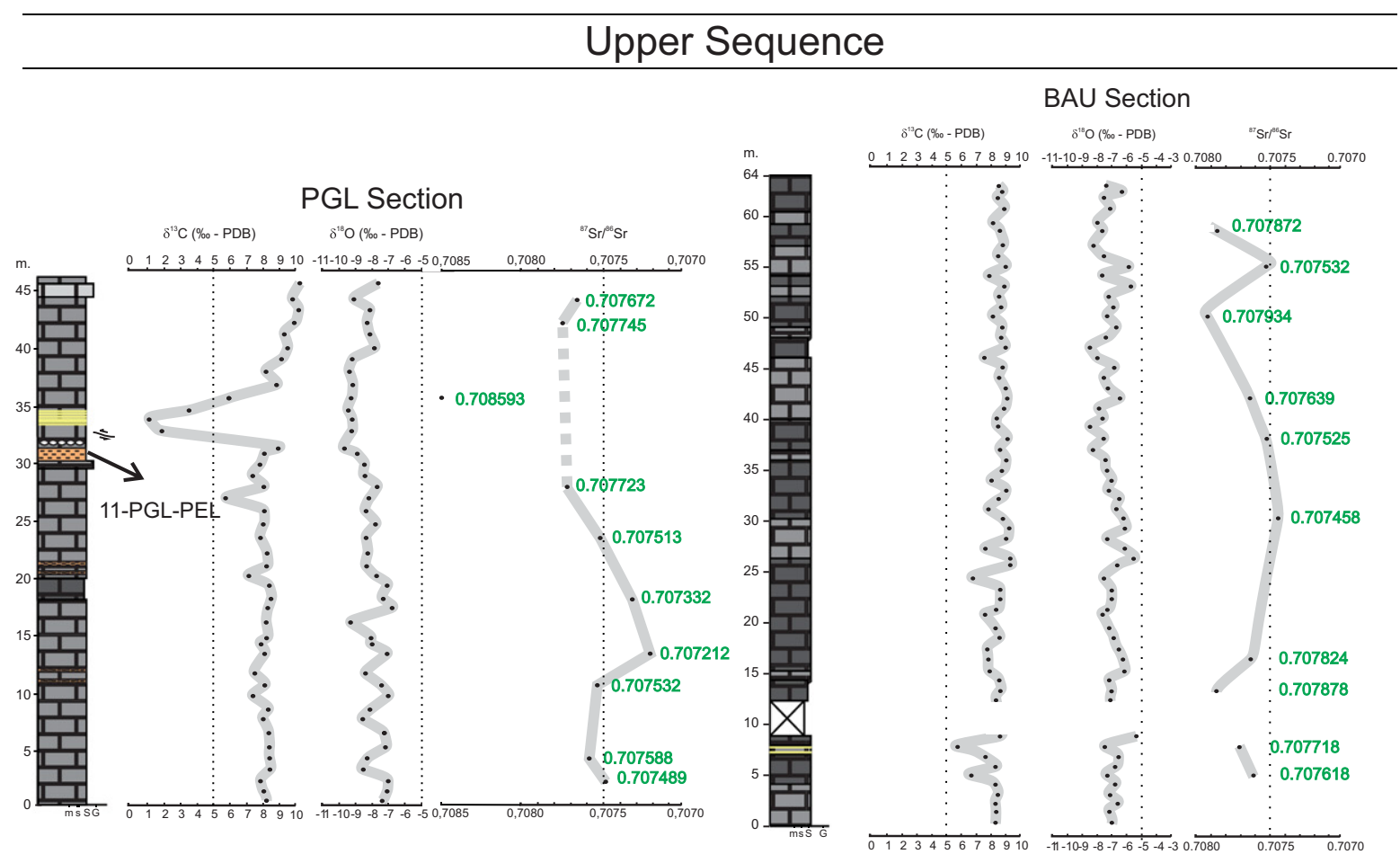

\section{Basal Sequence}

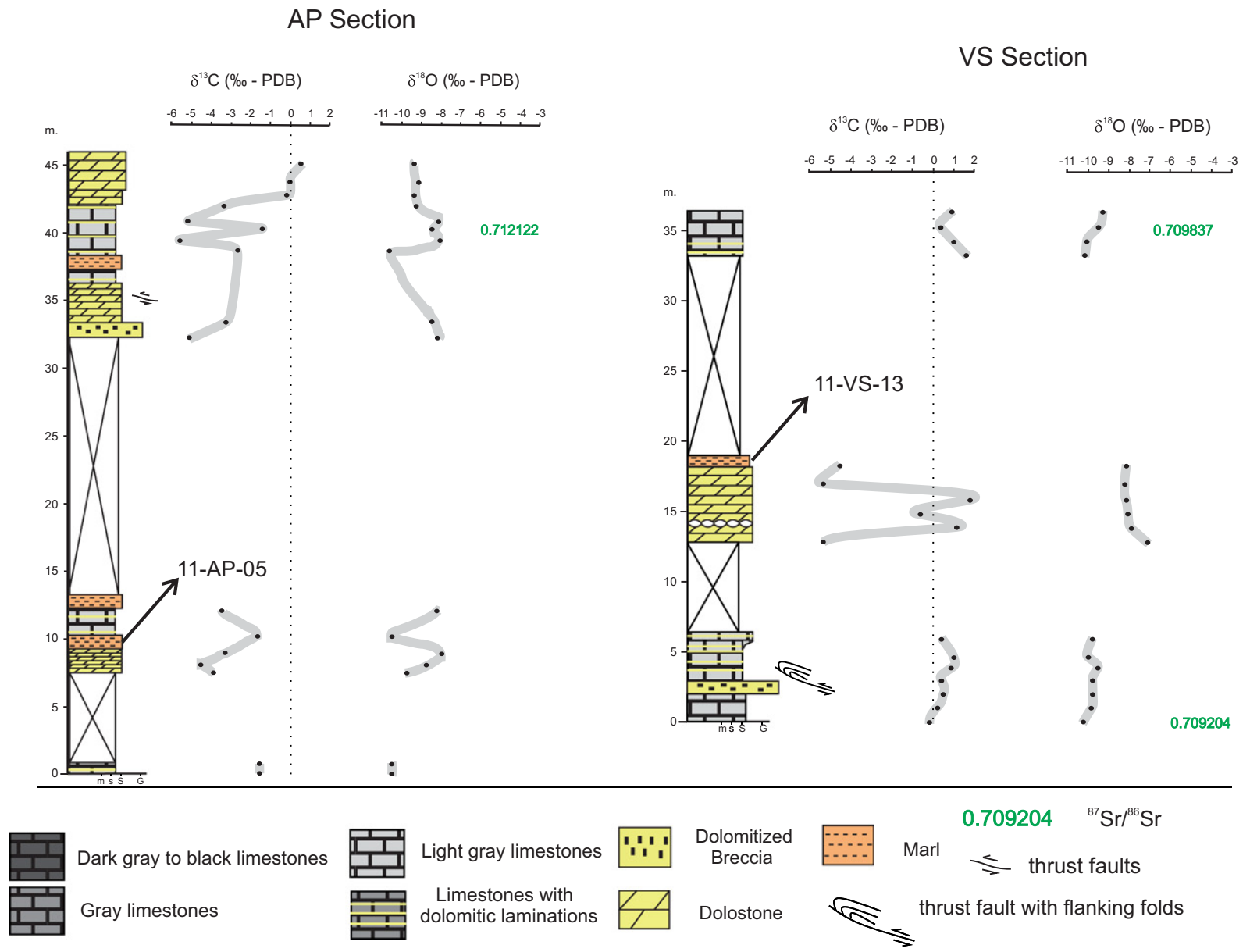

Fig. 3. C, O and Sr isotope profiles of the studied sections. 
would represent a large interval between 750 and $600 \mathrm{Ma}$ using other compilations as reference (e.g., Jacobsen and Kaufman, 1999; Kusnetsov et al., 2013). It is worth mentioning that some observed sedimentary features common in cap carbonates of distinct ages, such as aragonite pseudomorphs, have been also considered as "typical" of post-Marinoan cap carbonates (Caxito et al., 2012).

On the other hand, $\delta^{44} \mathrm{Ca}$ trends reported for the cap carbonates of the Sete Lagoas Formation (Silva-Tamayo et al., 2010) are quite similar to those of the Twyitya Formation, a post-Sturtian carbonate succession of NW Canada. Such trends are characterized by a negative excursion immediately in the basal cap carbonates, whereas post-Marinoan successions display such negative excursion higher-up in the sections as a result of initial dissolution of ancient carbonates enriched in ${ }^{44} \mathrm{Ca}$ that were not available on the aftermath of the Sturtian glaciation (Silva-Tamayo et al., 2010). After the older glacial event, siliciclastic rocks were preferentially weathered during the fallback of the ice sheet, delivering a large amount of ${ }^{40} \mathrm{Ca}$ into the oceans that resulted in an initial negative excursion.

In this scenario, we present new geochronological (U-Pb, Sm-Nd) and isotope chemostratigraphic $(\mathrm{C}, \mathrm{O}, \mathrm{Sr})$ data obtained, respectively, on marls and carbonates of the Sete Lagoas Formation. The purpose of this work is to constrain ages for both sequences of the Sete Lagoas Formation on the eastern portion of the basin and to test the efficiency of $\mathrm{Sr}$ isotopes on correlating the Bambuí Group to other Neoproterozoic carbonate-siliciclastic successions.

\section{Geological setting and studied sections}

The São Francisco craton sedimentary covers extend for more than $300,000 \mathrm{~km}^{2}$ (Fig. 1), whereas the Archaean-Palaeoproterozoic basement is mainly exposed in the southern tip and northeast sector of the cratonic region (Teixeira et al., 2000; Alkmin and Martins-Neto, 2012).

The Neoproterozoic cratonic cover comprises, at the base, sparse glacial deposits (e.g., Jequitaí and Carrancas formations), most of them of continental nature, and the marine carbonate-siliciclastic sequences of the Bambuí Group (Rocha-Campos and Hasui, 1981; Karfunkel and
Hoppe, 1988; Martins-Neto and Hercos, 2002; Vieira et al., 2007; Alkmin and Martins-Neto, 2012; Kuchenbecker et al., 2013). Despite tectonic discontinuities (e.g., thrust faults along craton limits), the Neoproterozoic glaciogenic cover has equivalents in both the Araçuaí and Brasília belts, represented by units of the Macaúbas and Ibiá groups, respectively (Uhlein et al., 1999; Dardenne, 2000; Martins-Neto et al., 2001; Pedrosa-Soares et al., 2011a; Babinski et al., 2012).

The Bambuí Group records deposition related to a marine transgression and flexural subsidence of the São Francisco craton, owing to the overload caused by the Brasília and Araçuaí belts' thrust onto cratonic borders (Martins-Neto et al., 2001; Alkmin and Martins-Neto, 2012). In fact, this group is bounded by thrusts along the edges of the São Francisco craton (Fig. 1). At least in the Araçuaí belt, the carbonatepelite succession typical of the Bambuí Group has not been found (Pedrosa-Soares et al., 2008, 2011a; Babinski et al., 2012).

In the study region, located close to the southeast thrust boundary between the São Francisco craton and the Araçuaí belt (Fig. 1), the Bambuí Group sharply overlies the Archaean-Palaeoproterozoic basement and is separated from the basement by a shear zone, which is marked by well-developed foliation and stretching lineations, owing to the oriented recrystallization of calcite, mica and chlorite. Deformation and low grade metamorphic recrystallization are more intense in rocks with a pelitic matrix, like marls and carbonates rich in pelitic laminae. This shear zone may show mineral recrystallization assisted by hydrothermal activity, forming sulphides, epidote and other minerals. Well-preserved carbonate layers are found between shear zones, and far from the boundary thrust zone.

According to Dardenne (1978), the Bambuí Group can be subdivided into five units, from base to top (Fig. 1): (i) the Sete Lagoas Formation, composed of limestones and dolomites with interbeded pelitic rock layers (thickness $\leq 500 \mathrm{~m}$ ); (ii) the Serra de Santa Helena Formation, mainly composed of shales and siltstones with interbeded limestones and sandstones (640 m); (iii) the Lagoa do Jacaré Formation, which comprises limestones, siltstones and marbles (350 m); (iv) the Serra da Saudade Formation, constituted of siltstones, green shales and a few limestone

Table 1

Major element contents of the analysed carbonates.

\begin{tabular}{|c|c|c|c|c|c|c|c|c|c|c|c|c|}
\hline & Sample & $\mathrm{m}$. & $\mathrm{Si}$ & $\mathrm{Al}$ & Mn & $\mathrm{Mg}$ & $\mathrm{Ca}$ & $\mathrm{Na}$ & K & $\mathrm{Ti}$ & $\mathrm{P}$ & $\mathrm{Fe}$ \\
\hline \multirow[t]{3}{*}{ AP section } & 11-AP-01 & 0.0 & n.a. & n.a. & n.a. & n.a. & n.a. & n.a. & n.a. & n.a. & n.a. & n.a. \\
\hline & 11-AP-06 & 10.3 & n.a. & n.a. & n.a. & n.a. & n.a. & n.a. & n.a. & n.a. & n.a. & n.a. \\
\hline & 11-AP-14 & 38.3 & n.a. & n.a. & n.a. & n.a. & n.a. & n.a. & n.a. & n.a. & n.a. & n.a. \\
\hline \multirow[t]{5}{*}{ VS section } & 11-VS-01 & 0.0 & n.a. & n.a. & n.a. & n.a. & n.a. & n.a. & n.a. & n.a. & n.a. & n.a. \\
\hline & 11-VS-06 & 4.6 & n.a. & n.a. & n.a. & n.a. & n.a. & n.a. & n.a. & n.a. & n.a. & n.a. \\
\hline & 11-VS-07 & 5.8 & n.a. & n.a. & n.a. & n.a. & n.a. & n.a. & n.a. & n.a. & n.a. & n.a. \\
\hline & 11-VS-14 & 33.2 & n.a. & n.a. & n.a. & n.a. & n.a. & n.a. & n.a. & n.a. & n.a. & n.a. \\
\hline & 11-VS-16 & 35.2 & n.a. & n.a. & n.a. & n.a. & n.a. & n.a. & n.a. & n.a. & n.a. & n.a. \\
\hline \multirow[t]{11}{*}{ BAU section } & 11-BAU-06 & 5.0 & 0.72 & 0.13 & $<0.01$ & 0.22 & 38.66 & $<0.01$ & 0.04 & 0.03 & 0.09 & 0.17 \\
\hline & 11-BAU-09 & 7.8 & 0.69 & 0.13 & 0.01 & 0.24 & 39.05 & 0.02 & 0.07 & 0.03 & 0.09 & 0.19 \\
\hline & 11-BAU-12 & 13.3 & 0.29 & 0.05 & 0.01 & 0.20 & 39.32 & 0.01 & 0.04 & 0.02 & 0.05 & 0.13 \\
\hline & 11-BAU-15 & 16.4 & 0.17 & 0.02 & 0.01 & 0.19 & 39.62 & 0.01 & 0.02 & 0.02 & 0.04 & 0.11 \\
\hline & 11-BAU-18 & 19.5 & 0.89 & 0.03 & 0.01 & 0.20 & 38.95 & $<0.01$ & 0.02 & 0.02 & 0.05 & 0.11 \\
\hline & 11-BAU-29 & 30.2 & 0.24 & 0.03 & 0.01 & 0.24 & 39.52 & 0.01 & 0.01 & 0.00 & 0.03 & 0.00 \\
\hline & 11-BAU-37 & 38.1 & 0.68 & 0.17 & 0.00 & 0.23 & 38.55 & $<0.01$ & 0.10 & 0.03 & 0.04 & 0.19 \\
\hline & 11-BAU-41 & 42.1 & 0.20 & 0.03 & 0.02 & 0.18 & 39.78 & $<0.01$ & 0.02 & 0.02 & 0.04 & 0.15 \\
\hline & 11-BAU-49 & 50.1 & 0.26 & 0.06 & 0.02 & 0.21 & 39.42 & $<0.01$ & 0.04 & 0.02 & 0.07 & 0.15 \\
\hline & 11-BAU-54 & 55.0 & 0.14 & 0.01 & 0.01 & 0.11 & 39.62 & $<0.01$ & 0.00 & 0.02 & 0.04 & 0.11 \\
\hline & 11-BAU-57 & 58.3 & 0.11 & 0.02 & 0.02 & 0.22 & 39.08 & 0.01 & 0.02 & 0.02 & 0.03 & 0.13 \\
\hline \multirow{11}{*}{ PGL section } & 11-PGL-03 & 2.0 & 0.22 & 0.04 & 0.02 & 0.15 & 39.65 & $<0.01$ & 0.02 & 0.02 & 0.06 & 0.13 \\
\hline & 11-PGL-05 & 4.0 & 0.56 & 0.13 & 0.02 & 0.20 & 38.87 & $<0.01$ & 0.07 & 0.03 & 0.06 & 0.20 \\
\hline & 11-PGL-11 & 10.4 & 0.59 & 0.12 & 0.02 & 0.22 & 38.98 & $<0.01$ & 0.03 & 0.02 & 0.05 & 0.19 \\
\hline & 11-PGL-13 & 12.9 & 0.58 & 0.13 & 0.02 & 0.17 & 38.84 & $<0.01$ & 0.07 & 0.03 & 0.05 & 0.18 \\
\hline & 11-PGL-18 & 17.9 & 0.81 & 0.18 & 0.02 & 0.21 & 38.49 & $<0.01$ & 0.10 & 0.03 & 0.05 & 0.24 \\
\hline & 11-PGL-23 & 23.2 & 1.78 & 0.26 & 0.02 & 0.22 & 37.49 & $<0.01$ & 0.16 & 0.04 & 0.07 & 0.21 \\
\hline & 11-PGL-27 & 27.6 & 0.19 & 0.04 & 0.02 & 0.17 & 39.39 & 0.02 & 0.02 & 0.02 & 0.04 & 0.14 \\
\hline & 11-PGL-33 & 33.6 & 4.71 & 0.94 & 0.02 & 2.01 & 31.37 & $<0.01$ & 0.62 & 0.08 & 0.04 & 0.77 \\
\hline & 11-PGL-35 & 35.6 & 0.34 & 0.07 & 0.02 & 0.14 & 39.12 & 0.04 & 0.04 & 0.02 & 0.07 & 0.20 \\
\hline & 11-PGL-41 & 42.0 & 0.37 & 0.11 & 0.02 & 0.17 & 38.87 & 0.02 & 0.07 & 0.03 & 0.06 & 0.15 \\
\hline & 11-PGL-43 & 44.1 & 0.97 & 0.23 & 0.02 & 0.22 & 37.99 & 0.02 & 0.12 & 0.04 & 0.06 & 0.24 \\
\hline
\end{tabular}

Notes: n.a. $=$ not analysed. 
Table 2

$\mathrm{Rb}$ and $\mathrm{Sr}$ contents, geochemical ratios, $\mathrm{C}$ and $\mathrm{O}$ isotope values and ${ }^{87} \mathrm{Sr} /{ }^{86} \mathrm{Sr}$ ratios obtained on analysed carbonates.

\begin{tabular}{|c|c|c|c|c|c|c|c|c|c|c|c|c|c|}
\hline & Sample & $\mathrm{m}$. & $\mathrm{Rb}(\mathrm{ppm})$ & $\mathrm{Sr}(\mathrm{ppm})$ & $\mathrm{Mg} / \mathrm{Ca}$ & $\mathrm{Rb} / \mathrm{Sr}$ & $\mathrm{Mn} / \mathrm{Sr}$ & $\mathrm{Fe} / \mathrm{Sr}$ & $\mathrm{Ca} / \mathrm{Sr}$ & $\delta^{13} \mathrm{C}(\%)$ & $\delta^{18} \mathrm{O}(\%)$ & ${ }^{87} \mathrm{Sr} /{ }^{86} \mathrm{Sr}$ & error $(2 \sigma)$ \\
\hline \multirow[t]{20}{*}{ Ana Paula section } & 11-AP-01 & 0.0 & 27 & 311 & - & 0.087 & - & - & - & -1.6 & -10.5 & n.a. & n.a. \\
\hline & 11-AP-02 & 0.9 & - & - & - & - & - & - & - & -1.6 & -10.5 & n.a. & n.a. \\
\hline & 11-AP-03 & 7.5 & - & - & - & - & - & - & - & -3.9 & -9.8 & n.a. & n.a. \\
\hline & 11-AP-04 & 8.3 & - & - & - & - & - & - & - & -4.6 & -8.8 & n.a. & n.a. \\
\hline & 11-AP-05 & 9.3 & - & - & - & - & - & - & - & -3.3 & -8.0 & n.a. & n.a. \\
\hline & 11-AP-06 & 10.3 & 28 & 367 & - & 0.076 & - & - & - & -1.8 & -10.5 & n.a. & n.a. \\
\hline & 11-AP-07 & 12.3 & - & - & - & - & - & - & - & -3.5 & -8.3 & n.a. & n.a. \\
\hline & 11-AP-08 & 32.3 & - & - & - & - & - & - & - & -5.1 & -8.2 & n.a. & n.a. \\
\hline & 11-AP-09 & 33.4 & - & - & - & - & - & - & - & -3.3 & -8.5 & n.a. & n.a. \\
\hline & 11-AP-10 & 34.3 & - & - & - & - & - & - & - & $<\mathrm{LD}$ & $<\mathrm{LD}$ & n.a. & n.a. \\
\hline & 11-AP-11 & 35.3 & - & - & - & - & - & - & - & $<\mathrm{LD}$ & $<\mathrm{LD}$ & n.a. & n.a. \\
\hline & 11-AP-12 & 36.3 & - & - & - & - & - & - & - & $<\mathrm{LD}$ & $<\mathrm{LD}$ & n.a. & n.a. \\
\hline & 11-AP-14 & 38.3 & 21 & 533 & - & 0.039 & - & - & - & -2.7 & -10.7 & 0.712122 & 0.000072 \\
\hline & 11-AP-15 & 39.3 & - & - & - & - & - & - & - & -5.6 & -8.1 & n.a. & n.a. \\
\hline & 11-AP-16 & 40.5 & - & - & - & - & - & - & - & -1.4 & -8.5 & n.a. & n.a. \\
\hline & 11-AP-17 & 41.5 & - & - & - & - & - & - & - & -5.2 & -8.2 & n.a. & n.a. \\
\hline & 11-AP-18 & 42.2 & - & - & - & - & - & - & - & -3.4 & -9.3 & n.a. & n.a. \\
\hline & 11-AP-19 & 43.2 & - & - & - & - & - & - & - & -0.2 & -9.4 & n.a. & n.a. \\
\hline & 11-AP-20 & 44.2 & - & - & - & - & - & - & - & -0.1 & -9.2 & n.a. & n.a. \\
\hline & 11-AP-21 & 45.2 & - & - & - & - & - & - & - & 0.5 & -9.4 & n.a. & n.a. \\
\hline \multirow[t]{17}{*}{ Vespasiano section } & 11-VS-01 & 0.0 & 13 & 532 & - & 0.025 & - & - & - & -0.1 & -10.2 & 0.709204 & 0.000066 \\
\hline & 11-VS-02 & 1.0 & - & - & - & - & - & - & - & 0.1 & -9.9 & n.a. & n.a. \\
\hline & 11-VS-03 & 2.0 & - & - & - & - & - & - & - & 0.4 & -9.8 & n.a. & n.a. \\
\hline & 11-VS-04 & 2.9 & - & - & - & - & - & - & - & 0.3 & -9.8 & n.a. & n.a. \\
\hline & 11-VS-05 & 3.8 & - & - & - & - & - & - & - & 0.9 & -9.6 & n.a. & n.a. \\
\hline & 11-VS-06 & 4.6 & 23 & 373 & - & 0.063 & - & - & - & 1.0 & -10.0 & n.a. & n.a. \\
\hline & 11-VS-07 & 5.8 & 27 & 358 & - & 0.074 & - & - & - & 0.3 & -9.8 & n.a. & n.a. \\
\hline & 11-VS-08 & 12.8 & - & - & - & - & - & - & - & -5.3 & -7.1 & n.a. & n.a. \\
\hline & 11-VS-09 & 13.8 & - & - & - & - & - & - & - & 1.1 & -7.9 & n.a. & n.a. \\
\hline & $11-\mathrm{VS}-10$ & 14.7 & - & - & - & - & - & - & - & -0.7 & -8.1 & n.a. & n.a. \\
\hline & 11-VS-11 & 15.7 & - & - & - & - & - & - & - & 1.8 & -8.2 & n.a. & n.a. \\
\hline & 11-VS-12 & 17.0 & - & - & - & - & - & - & - & -5.3 & -8.3 & n.a. & n.a. \\
\hline & 11-VS-13 & 18.3 & - & - & - & - & - & - & - & -4.6 & -8.2 & n.a. & n.a. \\
\hline & 11-VS-14 & 33.2 & 27 & 272 & - & 0.101 & - & - & - & 1.6 & -10.2 & n.a. & n.a. \\
\hline & 11-VS-15 & 34.2 & - & - & - & - & - & - & - & 1.0 & -10.1 & n.a. & n.a. \\
\hline & 11-VS-16 & 35.2 & 27 & 397 & - & 0.067 & - & - & - & 0.3 & -9.6 & 0.709837 & 0.000062 \\
\hline & 11-VS-17 & 36.4 & - & - & - & - & - & - & - & 0.9 & -9.3 & n.a. & n.a. \\
\hline \multirow[t]{38}{*}{ Pedra do Baú section } & 11-BAU-01 & 0.4 & - & - & - & - & - & - & - & 8.2 & -7.0 & n.a. & n.a. \\
\hline & 11-BAU-02 & 1.4 & - & - & - & - & - & - & - & 8.3 & -7.2 & n.a. & n.a. \\
\hline & 11-BAU-03 & 2.2 & - & - & - & - & - & - & - & 8.2 & -6.7 & n.a. & n.a. \\
\hline & 11-BAU-04 & 3.1 & - & - & - & - & - & - & - & 8.4 & -7.1 & n.a. & n.a. \\
\hline & 11-BAU-05 & 4.1 & - & - & - & - & - & - & - & 8.2 & -6.8 & n.a. & \\
\hline & 11-BAU-06 & 5.0 & 5 & 2176 & 0.006 & 0.002 & $<0.001$ & 0.804 & 178 & 6.7 & -7.3 & 0.707618 & 0.000054 \\
\hline & 11-BAU-07 & 5.8 & - & - & - & - & - & - & - & 8.2 & -6.8 & n.a. & \\
\hline & 11-BAU-08 & 6.8 & - & - & - & - & - & - & - & 7.6 & -6.6 & n.a. & \\
\hline & 11-BAU-09 & 7.8 & 7 & 1045 & 0.006 & 0.007 & 0.074 & 1.807 & 374 & 5.8 & -7.5 & 0.707718 & 0.000063 \\
\hline & 11-BAU-10 & 8.8 & - & - & - & - & - & - & - & 8.6 & -5.3 & n.a. & \\
\hline & 11-BAU-11 & 12.3 & - & - & - & - & - & - & - & 8.3 & -7.1 & n.a. & \\
\hline & 11-BAU-12 & 13.3 & 5 & 1830 & 0.005 & 0.003 & 0.042 & 0.688 & 215 & 8.6 & -7.0 & 0.707878 & 0.000050 \\
\hline & 11-BAU-13 & 14.3 & - & - & - & - & - & - & - & 8.5 & -7.2 & n.a. & \\
\hline & 11-BAU-14 & 15.3 & - & - & - & - & - & - & - & 7.9 & -6.1 & n.a. & \\
\hline & 11-BAU-15 & 16.4 & 4 & 1406 & 0.005 & 0.003 & 0.055 & 0.796 & 282 & 7.8 & -6.2 & 0.707824 & 0.000050 \\
\hline & 11-BAU-16 & 17.4 & - & - & - & - & - & - & - & 7.7 & -6.5 & n.a. & \\
\hline & 11-BAU-17 & 18.5 & - & - & - & - & - & - & - & 8.5 & -6.9 & n.a. & \\
\hline & 11-BAU-18 & 19.5 & 4 & 1546 & 0.005 & 0.002 & 0.050 & 0.724 & 252 & 8.3 & -7.1 & 0.707636 & 0.000056 \\
\hline & 11-BAU-19 & 20.8 & - & - & - & - & - & - & - & 7.6 & -7.7 & n.a. & n.a. \\
\hline & 11-BAU-20 & 21.3 & - & - & - & - & - & - & - & 8.2 & -7.3 & n.a. & n.a. \\
\hline & 11-BAU-21 & 22.3 & - & - & - & - & - & - & - & 8.6 & -7.0 & n.a. & n.a. \\
\hline & 11-BAU-22 & 23.3 & - & - & - & - & - & - & - & 8.6 & -7.0 & n.a. & n.a. \\
\hline & 11-BAU-23 & 24.4 & - & - & - & - & - & - & - & 6.8 & -7.6 & n.a. & n.a. \\
\hline & 11-BAU-24 & 25.5 & - & - & - & - & - & - & - & 9.3 & -6.7 & n.a. & n.a. \\
\hline & 11-BAU-25 & 26.3 & - & - & - & - & - & - & - & 9.3 & -5.6 & n.a. & n.a. \\
\hline & 11-BAU-26 & 27.3 & - & - & - & - & - & - & - & 7.6 & -6.1 & n.a. & n.a. \\
\hline & 11-BAU-27 & 28.3 & - & - & - & - & - & - & - & 9.0 & -7.3 & n.a. & n.a. \\
\hline & 11-BAU-28 & 29.3 & - & - & - & - & - & - & - & 9.2 & -6.1 & n.a. & n.a. \\
\hline & 11-BAU-29 & 30.2 & 4 & 1885 & 0.006 & 0.002 & 0.041 & $<0.001$ & 210 & 8.8 & -6.2 & 0.707458 & 0.000059 \\
\hline & 11-BAU-30 & 31.2 & - & - & - & - & - & - & - & 7.8 & -6.7 & n.a. & n.a. \\
\hline & 11-BAU-31 & 32.2 & - & - & - & - & - & - & - & 8.5 & -6.5 & n.a. & n.a. \\
\hline & 11-BAU-32 & 33.0 & - & - & - & - & - & - & - & 9.0 & -7.2 & n.a. & n.a. \\
\hline & 11-BAU-33 & 34.0 & - & - & - & - & - & - & - & 8.0 & -7.0 & n.a. & n.a. \\
\hline & 11-BAU-34 & 35.0 & - & - & - & - & - & - & - & 8.8 & -7.3 & n.a. & n.a. \\
\hline & 11-BAU-35 & 36.0 & - & - & - & - & - & - & - & 9.0 & -7.4 & n.a. & n.a. \\
\hline & 11-BAU-36 & 37.0 & - & - & - & - & - & - & - & 8.6 & -8.3 & n.a. & n.a. \\
\hline & 11-BAU-37 & 38.1 & 7 & 2160 & 0.006 & 0.003 & $<0.001$ & 0.874 & 178 & 9.1 & -7.6 & 0.707525 & 0.000059 \\
\hline & 11-BAU-38 & 39.3 & - & - & - & - & - & - & - & 8.4 & -8.5 & n.a. & n.a. \\
\hline
\end{tabular}


Table 2 (continued)

\begin{tabular}{|c|c|c|c|c|c|c|c|c|c|c|c|c|c|}
\hline & Sample & $\mathrm{m}$. & $\mathrm{Rb}(\mathrm{ppm})$ & $\mathrm{Sr}(\mathrm{ppm})$ & $\mathrm{Mg} / \mathrm{Ca}$ & $\mathrm{Rb} / \mathrm{Sr}$ & $\mathrm{Mn} / \mathrm{Sr}$ & $\mathrm{Fe} / \mathrm{Sr}$ & $\mathrm{Ca} / \mathrm{Sr}$ & $\delta^{13} \mathrm{C}(\%)$ & $\delta^{18} \mathrm{O}(\%)$ & ${ }^{87} \mathrm{Sr} /{ }^{86} \mathrm{Sr}$ & error $(2 \sigma)$ \\
\hline \multirow{23}{*}{ Pedra do Baú section } & 11-BAU-39 & 40.1 & - & - & - & - & - & - & - & 8.3 & -7.7 & n.a. & n.a. \\
\hline & 11-BAU-41 & 42.1 & 3 & 1720 & 0.005 & 0.002 & 0.090 & 0.854 & 231 & 9.1 & -6.4 & 0.707639 & 0.000055 \\
\hline & 11-BAU-42 & 43.1 & - & - & - & - & - & - & - & 9.0 & -7.2 & n.a. & n.a. \\
\hline & 11-BAU-43 & 44.1 & - & - & - & - & - & - & - & 8.5 & -7.6 & n.a. & n.a. \\
\hline & 11-BAU-44 & 45.1 & - & - & - & - & - & - & - & 8.8 & -6.9 & n.a. & n.a. \\
\hline & 11-BAU-45 & 46.1 & - & - & - & - & - & - & - & 7.5 & -8.0 & n.a. & n.a. \\
\hline & 11-BAU-46 & 47.1 & - & - & - & - & - & - & - & 9.0 & -8.5 & n.a. & n.a. \\
\hline & 11-BAU-47 & 48.1 & - & - & - & - & - & - & - & 8.7 & -7.4 & n.a. & n.a. \\
\hline & 11-BAU-48 & 49.1 & - & - & - & - & - & - & - & 8.8 & -6.7 & n.a. & n.a. \\
\hline & 11-BAU-49 & 50.1 & 4 & 1809 & 0.005 & 0.002 & 0.086 & 0.851 & 218 & 8.1 & -7.3 & 0.707934 & 0.000049 \\
\hline & 11-BAU-50 & 51.1 & - & - & - & - & - & - & - & 8.7 & -6.9 & n.a. & n.a. \\
\hline & 11-BAU-51 & 52.1 & - & - & - & - & - & - & - & 8.5 & -7.2 & n.a. & n.a. \\
\hline & 11-BAU-52 & 53.1 & - & - & - & - & - & - & - & 8.9 & -5.7 & n.a. & n.a. \\
\hline & 11-BAU-53 & 54.1 & - & - & - & - & - & - & - & 7.9 & -7.7 & n.a. & n.a. \\
\hline & 11-BAU-54 & 55.0 & 3 & 1045 & 0.003 & 0.003 & 0.074 & 1.071 & 379 & 9.0 & -5.8 & 0.707532 & 0.000072 \\
\hline & 11-BAU-55 & 56.1 & - & - & - & - & - & - & - & 8.4 & -7.6 & n.a. & n.a. \\
\hline & 11-BAU-56 & 57.1 & - & - & - & - & - & - & - & 8.8 & -8.2 & n.a. & n.a. \\
\hline & 11-BAU-57 & 58.3 & 4 & 1929 & 0.006 & 0.002 & 0.120 & 0.689 & 203 & 8.6 & -7.7 & 0.707872 & 0.000054 \\
\hline & 11-BAU-58 & 59.2 & - & - & - & - & - & - & - & 8.1 & -8.0 & n.a. & n.a. \\
\hline & 11-BAU-59 & 60.4 & - & - & - & - & - & - & - & 8.9 & -7.1 & n.a. & n.a. \\
\hline & 11-BAU-60 & 61.4 & - & - & - & - & - & - & - & 8.4 & -7.6 & n.a. & n.a. \\
\hline & 11-BAU-61 & 62.4 & - & - & - & - & - & - & - & 8.8 & -6.3 & n.a. & n.a. \\
\hline & 11-BAU-62 & 63.0 & - & - & - & - & - & - & - & 8.5 & -7.4 & n.a. & n.a. \\
\hline \multirow{44}{*}{ Parque da Gruta da Lapinha section } & 11-PGL-01 & 0.0 & - & - & - & - & - & - & - & 8.2 & -7.4 & n.a. & n.a. \\
\hline & 11-PGL-02 & 1.0 & - & - & - & - & - & - & - & 8.1 & -7.1 & n.a. & n.a. \\
\hline & 11-PGL-03 & 2.0 & 2 & 2563 & 0.004 & 0.001 & 0.060 & 0.519 & 155 & 7.9 & -7.1 & 0.707489 & 0.000064 \\
\hline & 11-PGL-04 & 3.0 & - & - & - & - & - & - & - & 8.4 & -8.5 & n.a. & n.a. \\
\hline & 11-PGL-05 & 4.0 & 3 & 2755 & 0.005 & 0.001 & 0.056 & 0.711 & 141 & 8.4 & -8.3 & 0.707588 & 0.000066 \\
\hline & 11-PGL-06 & 5.0 & - & - & - & - & - & - & - & 8.4 & -7.2 & n.a. & n.a. \\
\hline & 11-PGL-07 & 6.0 & - & - & - & - & - & - & - & 8.3 & -7.3 & n.a. & n.a. \\
\hline & 11-PGL-08 & 7.2 & - & - & - & - & - & - & - & 8.0 & -8.5 & n.a. & n.a. \\
\hline & 11-PGL-09 & 8.2 & - & - & - & - & - & - & - & 8.3 & -8.1 & n.a. & n.a. \\
\hline & 11-PGL-10 & 9.2 & - & - & - & - & - & - & - & 7.4 & -7.0 & n.a. & n.a. \\
\hline & 11-PGL-11 & 10.4 & 2 & 2809 & 0.006 & 0.001 & 0.055 & 0.672 & 139 & 8.0 & -7.5 & 0.707532 & 0.000065 \\
\hline & 11-PGL-12 & 11.4 & - & - & - & - & - & - & - & 7.5 & -8.4 & n.a. & n.a. \\
\hline & 11-PGL-13 & 12.9 & 4 & 3393 & 0.005 & 0.001 & 0.046 & 0.536 & 114 & 8.2 & -7.1 & 0.707212 & 0.000062 \\
\hline & 11-PGL-14 & 13.9 & - & - & - & - & - & - & - & 7.8 & -8.0 & n.a. & n.a. \\
\hline & 11-PGL-15 & 14.9 & - & - & - & - & - & - & - & 8.3 & -8.1 & n.a. & n.a. \\
\hline & 11-PGL-16 & 15.9 & - & - & - & - & - & - & - & 8.4 & -9.3 & n.a. & n.a. \\
\hline & 11-PGL-17 & 16.9 & - & - & - & - & - & - & - & 8.4 & -6.8 & n.a. & n.a. \\
\hline & 11-PGL-18 & 17.9 & 5 & 2758 & 0.005 & 0.002 & 0.056 & 0.862 & 140 & 8.5 & -7.4 & 0.707332 & 0.000075 \\
\hline & 11-PGL-19 & 18.9 & - & - & - & - & - & - & - & 8.4 & -7.1 & n.a. & n.a. \\
\hline & 11-PGL-20 & 19.8 & - & - & - & - & - & - & - & 7.2 & -7.7 & n.a. & n.a. \\
\hline & 11-PGL-21 & 20.8 & - & - & - & - & - & - & - & 8.2 & -8.3 & n.a. & n.a. \\
\hline & 11-PGL-22 & 21.8 & - & - & - & - & - & - & - & 8.2 & -8.3 & n.a. & n.a. \\
\hline & 11-PGL-23 & 23.2 & 7 & 3650 & 0.006 & 0.002 & 0.064 & 0.575 & 103 & 7.8 & -8.4 & 0.707513 & 0.000072 \\
\hline & 11-PGL-24 & 24.4 & - & - & - & - & - & - & - & 8.0 & -7.8 & n.a. & n.a. \\
\hline & 11-PGL-25 & 25.5 & - & - & - & - & - & - & - & 8.1 & -8.4 & n.a. & n.a. \\
\hline & 11-PGL-26 & 26.6 & - & - & - & - & - & - & - & 5.8 & -8.2 & n.a. & n.a. \\
\hline & 11-PGL-27 & 27.6 & 3 & 2260 & 0.004 & 0.001 & 0.069 & 0.619 & 174 & 8.1 & -7.7 & 0.707723 & 0.000063 \\
\hline & 11-PGL-28 & 28.6 & - & - & - & - & - & - & - & 7.4 & -8.5 & n.a. & n.a. \\
\hline & 11-PGL-29 & 29.6 & - & - & - & - & - & - & - & 7.8 & -8.5 & n.a. & n.a. \\
\hline & 11-PGL-30 & 30.1 & - & - & - & - & - & - & - & 8.1 & -8.9 & n.a. & n.a. \\
\hline & 11-PGL-31 & 31.6 & - & - & - & - & - & - & - & 8.9 & -9.7 & n.a. & n.a. \\
\hline & 11-PGL-32 & 32.6 & - & - & - & - & - & - & - & 1.9 & -9.3 & n.a. & n.a. \\
\hline & 11-PGL-33 & 33.6 & 26 & 462 & 0.064 & 0.057 & 0.503 & 16.655 & 679 & 1.2 & -9.3 & n.a. & n.a. \\
\hline & 11-PGL-34 & 34.6 & - & - & - & - & - & - & - & 3.6 & -9.4 & n.a. & n.a. \\
\hline & 11-PGL-35 & 35.6 & 3 & 2704 & 0.004 & 0.001 & 0.086 & 0.750 & 145 & 6.0 & -9.3 & 0.708593 & 0.000076 \\
\hline & 11-PGL-36 & 36.6 & - & - & - & - & - & - & - & 8.9 & -9.2 & n.a. & n.a. \\
\hline & 11-PGL-37 & 37.8 & - & - & - & - & - & - & - & 8.2 & -9.3 & n.a. & n.a. \\
\hline & 11-PGL-38 & 38.8 & - & - & - & - & - & - & - & 9.1 & -9.2 & n.a. & n.a. \\
\hline & 11-PGL-39 & 39.8 & - & - & - & - & - & - & - & 9.5 & -7.9 & n.a. & n.a. \\
\hline & 11-PGL-40 & 41.0 & - & - & - & - & - & - & - & 9.3 & -8.1 & n.a. & n.a. \\
\hline & 11-PGL-41 & 42.0 & 4 & 3200 & 0.005 & 0.001 & 0.048 & 0.481 & 121 & 9.9 & -8.3 & 0.707745 & 0.000062 \\
\hline & 11-PGL-42 & 43.1 & - & - & - & - & - & - & - & 10.2 & -8.1 & n.a. & n.a. \\
\hline & 11-PGL-43 & 44.1 & 6 & 2961 & 0.006 & 0.002 & 0.052 & 0.803 & 128 & 9.8 & -9.1 & 0.707672 & 0.000068 \\
\hline & 11-PGL-44 & 45.4 & - & - & - & - & - & - & - & 10.2 & -7.6 & n.a. & n.a. \\
\hline
\end{tabular}

Notes: - = no data for calculation; n.a. = not analysed.

layers (200 m); and (v) the Três Marias Formation, composed by arkosic sandstones and siltstones. The Bambuí Group records a marine transgression caused by flexural subsidence of the São Francisco Craton, due to the development of the Brasília Belt at the west of the craton (Martins-Neto et al., 2001; Alkmin and Martins-Neto, 2012).
The Sete Lagoas Formation comprises two shallowing-upward sequences, recording two transgressive events (Vieira et al., 2007). Its maximum thickness in the studied area is around $200 \mathrm{~m}$. The basal sequence started with the deposition of seafloor precipitates, which include aragonite pseudomorphs, carbonate mud and cement, characterized by 
Table 3

Summary of LA-ICPMS U-Pb zircon results for sample 11-AP-05.

\begin{tabular}{|c|c|c|c|c|c|c|c|c|c|c|c|}
\hline \multirow[t]{2}{*}{ Grain spot } & \multicolumn{6}{|c|}{ Radiogenic ratios } & \multicolumn{4}{|l|}{ Age (Ma) } & \multirow[t]{2}{*}{$\%$ disc } \\
\hline & ${ }^{206} \mathrm{~Pb} /{ }^{238} \mathrm{U}$ & \pm & ${ }^{207} \mathrm{~Pb} /{ }^{235} \mathrm{U}$ & \pm & ${ }^{207} \mathrm{~Pb} /{ }^{206} \mathrm{~Pb}$ & \pm & ${ }^{206} \mathrm{~Pb} /{ }^{238} \mathrm{U}$ & \pm & ${ }^{207} \mathrm{~Pb} /{ }^{206} \mathrm{~Pb}$ & \pm & \\
\hline 1.1 & 0.1004 & 0.0009 & 0.8226 & 0.0133 & 0.0594 & 0.0005 & 617 & 5 & 575 & 18 & -7 \\
\hline 2.1 & 0.0980 & 0.0009 & 0.8102 & 0.0131 & 0.0601 & 0.0005 & 603 & 5 & 602 & 18 & 0 \\
\hline 3.1 & 0.0885 & 0.0009 & 0.7157 & 0.0148 & 0.0586 & 0.0009 & 547 & 5 & 544 & 33 & 0 \\
\hline 4.1 & 0.0939 & 0.0009 & 0.7722 & 0.0123 & 0.0594 & 0.0005 & 578 & 5 & 576 & 18 & 0 \\
\hline 5.1 & 0.0962 & 0.0009 & 0.7908 & 0.0124 & 0.0598 & 0.0005 & 592 & 5 & 590 & 18 & 0 \\
\hline 6.1 & 0.0973 & 0.0009 & 0.8052 & 0.0127 & 0.0597 & 0.0005 & 599 & 5 & 585 & 17 & -2 \\
\hline 7.1 & 0.0948 & 0.0009 & 0.7755 & 0.0122 & 0.0594 & 0.0005 & 584 & 5 & 576 & 17 & -1 \\
\hline 8.1 & 0.1026 & 0.0011 & 0.8722 & 0.0151 & 0.0609 & 0.0005 & 630 & 6 & 631 & 18 & 0 \\
\hline 9.1 & 0.0654 & 0.0008 & 0.5038 & 0.0101 & 0.0551 & 0.0006 & 408 & 5 & 410 & 22 & 0 \\
\hline 10.1 & 0.0965 & 0.0009 & 0.7952 & 0.0125 & 0.0599 & 0.0005 & 594 & 5 & 593 & 18 & 0 \\
\hline 11.1 & 0.0972 & 0.0009 & 0.8060 & 0.0126 & 0.0600 & 0.0005 & 598 & 5 & 596 & 18 & 0 \\
\hline 12.1 & 0.0970 & 0.0009 & 0.8016 & 0.0124 & 0.0596 & 0.0005 & 597 & 5 & 582 & 17 & -2 \\
\hline 13.1 & 0.0959 & 0.0009 & 0.7873 & 0.0121 & 0.0597 & 0.0005 & 591 & 5 & 588 & 17 & 0 \\
\hline
\end{tabular}

Notes: Errors are 1-sigma.

$\delta^{13} \mathrm{C}$ values as low as $-4.5 \%$. These isotopic and sedimentary features are typical of other cap carbonates found elsewhere in the globe (Grotzinger and Knoll, 1995; Kennedy, 1996; Hoffman and Schrag, 2002). These deposits are overlain by low organic matter content carbonates with $\delta^{13} \mathrm{C}$ values around $0 \%$. After a basin drowning, the second sequence started with abundant pelitic deposits immediately overlain by organic-rich black carbonates with $\delta^{13} \mathrm{C}$ values around $+8 \%$. This abrupt shift in Sete Lagoas Formation C isotopes is a basinal stratigraphic marker (Santos et al., 2000; Kuchenbecker, 2011). The $\delta^{13} \mathrm{C}$ values keep increasing upwards, reaching values as high as $+14 \%$ in stromatolitic carbonates just below the Serra de Santa Helena Formation (Iyer et al., 1995; Vieira et al., 2007).

\subsection{Studied area and sections}

The studied area is located at the central portion of Minas Gerais State, Brazil, between Lagoa Santa and Vespasiano cities (Fig. 2). The Bambuí Group unconformably overlies migmatites and gneisses of the São Francisco Craton basement exposed to the south of the area. Both lower and upper sequences of the Sete Lagoas Formation crop out in the study area. The lower sequence directly overlies the basement on the southeast and also outcrops in a $\mathrm{N}-\mathrm{S}$ segment that extends from Confins airport to the north of the area. The upper sequence crops out mainly at the northwest of Lagoa Santa City. An occurrence of the Carrancas Conglomerate is found nearby São José da Lapa City (Vieira et al., 2007). The Serra de Santa Helena deposits crop out around the Confins airport, the Lagoa Santa lake and to the northeast.

Two sections from the basal sequence (Vespasiano - VS, Ana Paula - AP) and two sections from the upper sequence (Pedra do Baú - BAU, Gruta da Lapinha Park - PGL) were described and sampled (Fig. 2). Although rocks from all sections display mineral recrystallization features, sedimentary structures were not completely obliterated.

Sections of the basal sequence comprise mainly light grey limestones and beige dolomites (Fig. 3). Carbonate grains are sand sized. The AP section is $46 \mathrm{~m}$ thick and display low-angle truncated lamination as the main sedimentary feature, whereas the VS section is $37 \mathrm{~m}$ thick and has plane parallel lamination as the main sedimentary structure. The percentage of siliciclastic sediments within the carbonate matrix ranges between 20 and $30 \%$ in the AP section decreasing to $5-7 \%$ in the VS section. Marl intercalations (siliciclastic content higher than $60 \%$ ) were described on both sections and sampled for geochronology (Fig. 3). Dolomite occurrences are usually found along to thrust faults with a W-vergence and associated with other tectonic structures (breccias, boudins), suggesting dolomitisation during tectonic events.

The upper sequence sections are characterized by massive outcrops of dark grey to black organic-rich limestones (Fig. 3). The carbonate grains are silt/sand sized. The BAU section is $64 \mathrm{~m}$ thick and the PGL section is $46 \mathrm{~m}$ thick. Both sections display plane parallel laminations as the main sedimentary structure and scarce low-angle truncated laminations. The percentage of siliciclastic material in the carbonate matrix is lower than $2 \%$. Marl intercalations occur in the PGL section and the thickest one was sampled for geochronology (Fig. 3).

\section{Materials and methods}

Four sections located between the cities of Vespasiano and Lagoa Santa (AP, VS, BAU and PGL; Fig. 2) were described in this study. A number of 143 carbonates and 3 marls were sampled for chemostratigraphy and geochronological analysis, respectively. All isotopic and geochronological analyses were carried out at the Center of Geochronological Research (CPGeo) of University of São Paulo.

Carbonate powders were obtained by microdrilling homogeneous sample areas, whereas fractured, weathered and mineral-filled zones were avoided. $\mathrm{C}$ and $\mathrm{O}$ analyses were carried out by reacting sample powders with $100 \% \mathrm{H}_{3} \mathrm{PO}_{4}$, under a He atmosphere. The $\mathrm{C}$ and $\mathrm{O}$ compositions of the $\mathrm{CO}_{2}$ extracted were then measured in a Delta Advantage mass spectrometer. The results are reported in the $\delta$ notation, relative to PDB standard.

$\mathrm{Sr}$ isotopic compositions were obtained only in carbonate samples with $\mathrm{Sr}$ contents higher than $300 \mathrm{ppm}$. Compositions were obtained using a two-step leaching technique. First leaching was performed by reacting $\sim 100 \mathrm{mg}$ of sample powders with $\mathrm{HCl} 0.1 \mathrm{~N}$ solution for $1 \mathrm{~h}$. After drying, the samples were centrifuged and washed three times with Milli Q water. These first leachates were discarded. The residues underwent reaction with $\mathrm{HCl} 1 \mathrm{~N}$ solution for $30 \mathrm{~min}$. After drying, the samples were again centrifuged and washed three times with Milli Q water. These second leachates were separated from the residue and purified by the ion exchange chromatography technique. Their ${ }^{87} \mathrm{Sr} /{ }^{86} \mathrm{Sr}$ ratios were measured on a Finnigan MAT 262 mass spectrometer. ${ }^{87} \mathrm{Sr} /{ }^{86} \mathrm{Sr}$ ratios were normalized for the value 0.1194 , and the average value of the NBS-987 standard measured during analysis was $0.710251 \pm 0.000043$.

$\mathrm{Rb}$ and $\mathrm{Sr}$ contents of carbonate rocks were measured in $10 \mathrm{~g}$ of whole rock samples by the X-Ray Fluorescence technique on a Philips PW 2510 X-ray spectrometer at the Fluorescence Laboratory/ICP-OES of USP. Other trace and major contents were determined by melting $0.2 \mathrm{~g}$ of whole rock samples with lithium metaborate/tetraborate, followed by diluted nitric acid attack and ICP-OES analysis at Acme Laboratory (Canada).

$\mathrm{U}-\mathrm{Pb}$ ages were obtained on detrital zircons retrieved from marl sample matrix. The acquisition of the isotopic data was performed using a NEPTUNE-ICP-MS coupled with a laser ablation system. To normalize the ${ }^{207} \mathrm{~Pb} /{ }^{206} \mathrm{~Pb}$ ratio the NIST 612 and external standards were used, while the ${ }^{206} \mathrm{~Pb} /{ }^{238} \mathrm{U}$ ratio was normalized by external standards. For mass bias correction the GJ standard (600 Ma; Elhlou et al., 2006) was used. 


\section{Results}

\subsection{Carbonate geochemistry}

The major element contents of each sample are shown in Table 1 and the $\mathrm{Rb}$ and $\mathrm{Sr}$ contents, $\mathrm{Mg} / \mathrm{Ca}, \mathrm{Rb} / \mathrm{Sr}, \mathrm{Mn} / \mathrm{Sr}, \mathrm{Fe} / \mathrm{Sr}$ and $\mathrm{Ca} / \mathrm{Sr}$ ratios and isotopic results are presented in Table 2.

Carbonates from the basal sequence are characterized by low $\mathrm{Sr}$ $(<550 \mathrm{ppm})$ and high $\mathrm{Rb}$ contents $(>10 \mathrm{ppm})$, as well as $\mathrm{Rb} / \mathrm{Sr}$ ratios ranging in the 0.02-0.10 interval. Therefore, only three samples were analysed for $\mathrm{Sr}$ isotopes, 11-AP-14, 11-VS-01 and 11-VS-13. The measured ${ }^{87} \mathrm{Sr} /{ }^{86} \mathrm{Sr}$ ratios are very radiogenic: $0.712122 \pm 0.000072$, $0.709204 \pm 0.000066$ and $0.709840 \pm 0.000062$, respectively. The $\delta^{13} \mathrm{C}$ values obtained on samples from the AP section range between -5.6 and $0.5 \%$ o (Table 2). No defined trend is observed from base to top and the samples display a large variation throughout stratigraphy. Consistent values are found only at the base $(-1.6 \%)$ and at the three uppermost samples $\left(\delta^{13} \mathrm{C}\right.$ values between -0.2 and $+0.5 \%$ o $) . \delta^{18} \mathrm{O}$ values from the AP section range from -10.7 to $-8 \%$ o and have a similar behaviour to that shown in the $C$ isotope values, although not so heterogeneous. Carbonates from the basal and upper portions of the VS section yielded $\delta^{13} \mathrm{C}$ values between -0.1 and $+1.6 \%$ ( Table 2 ), with a general upward increasing trend. Dolostones from the central portion yielded $\delta^{13} \mathrm{C}$ values ranging from -5.3 to $+1.8 \%$ o with a large variation among adjacent samples. The $\delta^{18} \mathrm{O}$ values obtained on basal and upper portion samples vary between -10.2 and $-9.3 \%$ and those obtained on central portion samples vary from -8.3 to $-7.1 \%$.

Carbonates from the upper sequence displayed high $\mathrm{Sr}(>1000 \mathrm{ppm})$ and low $\mathrm{Rb}$ contents ( $<10 \mathrm{ppm}$ ), as well as $\mathrm{Rb} / \mathrm{Sr}$ ratios lower than 0.01 (Table 2). As petrography revealed that these rocks are more homogenous than those from basal sequence and almost free from siliciclastic sediments on matrix admixture, further geochemical analyses were performed. Samples showed low Fe and Mn contents $(<0.01-0.29 \%$ and $<0.01-0.03 \%$, respectively), and low $\mathrm{Mg}$ content (0.11-0.26\%) compared to $\mathrm{Ca}(37.49-39.78 \%)$. The resulting $\mathrm{Mn} / \mathrm{Sr}, \mathrm{Fe} / \mathrm{Sr}, \mathrm{Ca} / \mathrm{Sr}$ and $\mathrm{Mg} / \mathrm{Ca}$ ratios are lower than $0.12,1.10,380$ and 0.01 , respectively (Table 2). These data suggested that the samples were ideal for $\mathrm{Sr}$ isotope analyses. The BAU section carbonates showed ${ }^{87} \mathrm{Sr} /{ }^{86} \mathrm{Sr}$ ratios ranging from $0.707458 \pm$ 0.000059 to $0.707934 \pm 0.000049$ and the $\mathrm{Sr}$ richest limestone (2176 ppm - sample 11-BAU-06) has a ratio of $0.707618 \pm 0.000054$. ${ }^{87} \mathrm{Sr} /{ }^{86} \mathrm{Sr}$ ratios of the PGL carbonates range from $0.707212 \pm 0.000062$ to $0.707745 \pm 0.000062$ and the $\mathrm{Sr}$ richest sample $(3650 \mathrm{ppm}$ - sample 11 -PGL-23) presented a ratio of $0.707513 \pm 0.000072$. Sample 11-PGL33 is out of these ranges. It has lower Sr content ( $462 \mathrm{ppm}$ ) and higher $\mathrm{Rb}$ content (26 ppm - Table 2) attached to an increase on the $\mathrm{Mg}$ content (Table 1) and was obtained from a partially dolomitised layer. The obtained ${ }^{87} \mathrm{Sr} /{ }^{86} \mathrm{Sr}$ ratio was $0.708593 \pm 0.000076$.

Samples from the BAU section presented $\delta^{13} \mathrm{C}$ values between +5.8 and $+9.3 \%$ o (Table 2). Sample 11-BAU-09 displayed the lowest value $(+5.8 \%$ ) and contained some millimetric dolomite laminations. The $\delta^{18} \mathrm{O}$ values obtained vary between -8.5 and $-5.3 \%$. $\delta{ }^{13} \mathrm{C}$ values obtained on carbonate samples from the PGL section range from +1.2 to $+10.2 \%$. Despite the wide interval, almost all samples present values higher than $+7 \%$. The lower values were obtained on carbonates collected between the 32-36 m interval that display millimetric dolomite laminations associated with a small thrust fault. The $\delta^{18} \mathrm{O}$ values obtained vary between -9.7 and $-6.8 \%$.

\subsection{Geochronological data}

Three layers of marl were sampled for geochronological analysis. The $\mathrm{U}-\mathrm{Pb}$ data is presented in Tables 3, 4 and 5 (AP, VS and PGL, respectively). Their stratigraphic position on sections AP, VS and PGL is shown in Fig. 3.

Only 13 zircon grains were retrieved from sample 11-AP-05 and their size range from 80 to $400 \mu \mathrm{m}$. Most of the zircons are prismatic and do not show igneous oscillatory zoning (Fig. 4). The concordant
${ }^{206} \mathrm{~Pb} /{ }^{238} \mathrm{U}$ ages obtained are in the 547-630 Ma interval (Fig. 5). About $77 \%$ of the grains show ages between 560 and $620 \mathrm{Ma}$ and a concordia age of $592.9 \pm 1.7$ Ma was obtained (Fig. 5).

Sample 11-VS-13 provided 77 zircon grains, which are mainly prismatic and round shaped and their size is no longer than $80 \mu \mathrm{m}$ (Fig. 4). Most of the grains show igneous oscillatory zoning on cathodoluminescence images. The two most important zircon populations ( 65\% of the grains) show peaks at 967 and 1068 (Figs. 5 and 6). Other important populations are 873 and $934 \mathrm{Ma}(6 \%), 1100 \mathrm{Ma}(4 \%)$ and $1271 \mathrm{Ma}$ (3\%). There are also Palaeoprotorozoic grains and an Archaean crystal dated at $3.68 \mathrm{Ga}$.

Seventy seven zircon grains were recovered from sample 11-PGLPEL. They are mainly prismatic and their size is no longer than $70 \mu \mathrm{m}$. The cathodoluminescence images reveal igneous oscillatory zoning (Fig. 4). The U-Pb ages indicate three important Neoproterozoic populations at $\sim 625$ (63\% of the grains), $~ 579$ and $~ 557$ Ma (26\% of the grains - Fig. 6).

\section{Discussion}

\subsection{Isotope chemostratigraphy}

The isotope chemostratigraphy is considered a powerful tool for correlating carbonate successions worldwide, especially the Proterozoic ones that lack robust fossil record (Jacobsen and Kaufman, 1999; Hoffman and Schrag, 2002; Halverson et al., 2010; Kusnetsov et al., 2013). But the effectiveness of the technique depends on the reliability of the acquired data and their representativeness regarding the isotope composition of the depositional environment (Melezhik et al., 2001; Frimmel, 2010; Kusnetsov et al., 2013). Therefore, it becomes necessary to evaluate whether the isotope record found within the studied sections of the Sete Lagoas Formation is original or modified by postdepositional events.

Section AP, the central portion of section VS and a carbonate layer from the top of the PGL section display a large oscillation on $\delta^{13} \mathrm{C}$ values when adjacent samples are compared. The lack of consistency strongly suggests post-depositional alteration of the $\mathrm{C}$ isotopic values. Carbonate rocks of those sectors are dolomitised or partially dolomitised (Fig. 3). Such dolomites are linked to tectonic structures, such as thrust faults, breccias and boudins, suggesting a tectonic induced dolomitisation. The large variation on $\delta^{13} \mathrm{C}$ values requires that a $\mathrm{C}$ enriched fluid interacted with the Sete Lagoas Formation carbonates, something not usual to in early diagenetic fluids (Brand and Veizer, 1980; Veizer et al., 1983). Moreover, $\delta^{13} \mathrm{C}$ vs. $\delta^{18} \mathrm{O}$ plots show no positive correlation between $\mathrm{C}$ and $\mathrm{O}$ isotopes and $\mathrm{Sr} / \mathrm{Ca}$ vs. Mn plots indicate no incorporation of Mn during post-depositional modification (Fig. 7). Both would be expected on a carbonate/diagenetic fluid interaction (Brand and Veizer, 1980; Veizer et al., 1983; Fölling and Frimmel, 2002; Derry, 2010). We therefore conclude that the $\delta^{13} \mathrm{C}$ values of these sectors are not original, early diagenetic, but were modified during tectonic dolomitisation.

The rest of the studied sections display consistent $\delta^{13} \mathrm{C}$ values that are considered primary and represent the original depositional marine environment. The $\mathrm{C}$ isotope curve of the Sete Lagoas Formation is quite similar along all the São Francisco Craton and the abrupt shift from $\delta{ }^{13} \mathrm{C}$ values around $0 \%$ at the basal sequence to values higher than $8 \%$ on the upper sequence is a regional stratigraphical mark (Santos et al., 2000). The best preserved values from $-1.6 \%$ to slightly positive ones for sections AP and VS confirm their stratigraphic position on the basal sequence proposed by our field and petrographic observations. Also, the absence of an expressive negative $C$ excursion indicates that such sections are above the basal cap carbonates. The highly positive values obtained for sections PGL and BAU also confirm that they belong to the upper sequence as pointed out by field descriptions.

Unlike $\delta^{13} \mathrm{C}$ values, the $\mathrm{Sr}$ isotope chemostratigraphy is not a good tool for intrabasinal correlation of the Sete Lagoas Formation sections, 
Table 4

Summary of LA-ICPMS U-Pb zircon results for sample 11-VS-13.

\begin{tabular}{|c|c|c|c|c|c|c|c|c|c|c|c|}
\hline \multirow[t]{2}{*}{ Grain spot } & \multicolumn{6}{|c|}{ Radiogenic ratios } & \multicolumn{4}{|l|}{ Age (Ma) } & \multirow[t]{2}{*}{$\%$ disc } \\
\hline & ${ }^{206} \mathrm{~Pb} /{ }^{238} \mathrm{U}$ & \pm & ${ }^{207} \mathrm{~Pb} /{ }^{235} \mathrm{U}$ & \pm & ${ }^{207} \mathrm{~Pb} /{ }^{206} \mathrm{~Pb}$ & \pm & ${ }^{206} \mathrm{~Pb} /{ }^{238} \mathrm{U}$ & \pm & ${ }^{207} \mathrm{~Pb} /{ }^{206} \mathrm{~Pb}$ & \pm & \\
\hline 1.1 & 0.1075 & 0.0009 & 0.9158 & 0.0230 & 0.0618 & 0.0014 & 658 & 5 & 661 & 50 & 0 \\
\hline 2.1 & 0.3881 & 0.0034 & 7.2441 & 0.1813 & 0.1355 & 0.0031 & 2114 & 16 & 2166 & 38 & 2 \\
\hline 3.1 & 0.1462 & 0.0008 & 1.4485 & 0.0349 & 0.0715 & 0.0016 & 880 & 4 & 972 & 47 & 9 \\
\hline 4.1 & 0.1615 & 0.0011 & 1.6741 & 0.0399 & 0.0744 & 0.0017 & 965 & 6 & 1054 & 46 & 8 \\
\hline 5.1 & 0.1804 & 0.0005 & 1.9055 & 0.0437 & 0.0768 & 0.0017 & 1069 & 2 & 1119 & 45 & 4 \\
\hline 6.1 & 0.1593 & 0.0004 & 1.5556 & 0.0358 & 0.0708 & 0.0016 & 953 & 2 & 951 & 46 & 0 \\
\hline 7.1 & 0.1753 & 0.0006 & 1.7942 & 0.0410 & 0.0741 & 0.0016 & 1041 & 3 & 1046 & 45 & 0 \\
\hline 8.1 & 0.1672 & 0.0009 & 1.6732 & 0.0391 & 0.0723 & 0.0016 & 996 & 5 & 994 & 46 & 0 \\
\hline 9.1 & 0.1514 & 0.0034 & 1.4870 & 0.0474 & 0.0712 & 0.0016 & 909 & 19 & 961 & 46 & 5 \\
\hline 10.1 & 0.2030 & 0.0027 & 2.2463 & 0.0556 & 0.0799 & 0.0019 & 1192 & 14 & 1197 & 47 & 0 \\
\hline 11.1 & 0.3264 & 0.0010 & 5.1319 & 0.1158 & 0.1140 & 0.0025 & 1821 & 5 & 1866 & 38 & 2 \\
\hline 12.1 & 0.1704 & 0.0009 & 1.7038 & 0.0400 & 0.0728 & 0.0016 & 1014 & 5 & 1009 & 45 & 0 \\
\hline 13.1 & 0.0868 & 0.0007 & 0.7032 & 0.0177 & 0.0584 & 0.0013 & 537 & 4 & 539 & 48 & 0 \\
\hline 14.1 & 0.1721 & 0.0009 & 1.8197 & 0.0257 & 0.0771 & 0.0009 & 1024 & 5 & 1127 & 23 & 9 \\
\hline 15.1 & 0.1625 & 0.0021 & 1.6080 & 0.0322 & 0.0738 & 0.0008 & 970 & 12 & 1038 & 23 & 6 \\
\hline 16.1 & 0.1823 & 0.0009 & 1.9409 & 0.0276 & 0.0776 & 0.0009 & 1079 & 5 & 1139 & 23 & 5 \\
\hline 17.1 & 0.1600 & 0.0008 & 1.6138 & 0.0224 & 0.0729 & 0.0008 & 957 & 4 & 1012 & 23 & 5 \\
\hline 18.1 & 0.1741 & 0.0011 & 1.8337 & 0.0272 & 0.0787 & 0.0009 & 1034 & 6 & 1168 & 22 & 11 \\
\hline 19.1 & 0.0839 & 0.0007 & 0.6741 & 0.0114 & 0.0589 & 0.0008 & 520 & 4 & 555 & 28 & 6 \\
\hline 20.1 & 0.1079 & 0.0009 & 1.0519 & 0.0178 & 0.0705 & 0.0010 & 661 & 5 & 941 & 30 & 30 \\
\hline 21.1 & 0.2249 & 0.0029 & 3.1970 & 0.0695 & 0.1044 & 0.0013 & 1308 & 15 & 1709 & 23 & 23 \\
\hline 22.1 & 0.1750 & 0.0009 & 1.8459 & 0.0266 & 0.0770 & 0.0009 & 1040 & 5 & 1123 & 23 & 7 \\
\hline 23.1 & 0.1639 & 0.0008 & 1.6113 & 0.0219 & 0.0717 & 0.0008 & 978 & 4 & 978 & 23 & 0 \\
\hline 24.1 & 0.7660 & 0.0047 & 39.4729 & 0.5579 & 0.3750 & 0.0041 & 3666 & 17 & 3684 & -24 & 0 \\
\hline 25.1 & 0.1628 & 0.0012 & 1.6116 & 0.0234 & 0.0720 & 0.0008 & 972 & 6 & 984 & 23 & 1 \\
\hline 26.1 & 0.2087 & 0.0019 & 2.2944 & 0.0375 & 0.0806 & 0.0009 & 1222 & 10 & 1217 & 22 & 0 \\
\hline 27.1 & 0.1797 & 0.0008 & 1.8358 & 0.0245 & 0.0743 & 0.0009 & 1065 & 4 & 1050 & 24 & -1 \\
\hline 28.1 & 0.1722 & 0.0005 & 1.7669 & 0.0221 & 0.0749 & 0.0009 & 1024 & 3 & 1068 & 23 & 4 \\
\hline 29.1 & 0.1530 & 0.0007 & 1.4913 & 0.0204 & 0.0711 & 0.0008 & 917 & 4 & 960 & 24 & 4 \\
\hline 30.1 & 0.1730 & 0.0006 & 1.7854 & 0.0228 & 0.0752 & 0.0009 & 1029 & 3 & 1077 & 23 & 4 \\
\hline 31.1 & 0.1796 & 0.0010 & 1.8670 & 0.0255 & 0.0747 & 0.0008 & 1065 & 6 & 1063 & 23 & 0 \\
\hline 32.1 & 0.3272 & 0.0013 & 5.6852 & 0.0770 & 0.1275 & 0.0015 & 1825 & 6 & 2061 & 20 & 11 \\
\hline 33.1 & 0.1447 & 0.0007 & 1.2975 & 0.0204 & 0.0680 & 0.0009 & 871 & 4 & 867 & 29 & 0 \\
\hline 34.1 & 0.3554 & 0.0016 & 6.0474 & 0.0922 & 0.1238 & 0.0016 & 1960 & 8 & 2010 & 22 & 2 \\
\hline 35.1 & 0.1789 & 0.0007 & 1.8763 & 0.0243 & 0.0764 & 0.0009 & 1061 & 4 & 1109 & 23 & 4 \\
\hline 36.1 & 0.1549 & 0.0016 & 1.5961 & 0.0276 & 0.0757 & 0.0010 & 928 & 9 & 1088 & 27 & 15 \\
\hline 37.1 & 0.1422 & 0.0011 & 1.4233 & 0.0205 & 0.0730 & 0.0008 & 857 & 6 & 1014 & 23 & 15 \\
\hline 38.1 & 0.2151 & 0.0033 & 2.4796 & 0.0574 & 0.0833 & 0.0011 & 1256 & 17 & 1282 & 25 & 2 \\
\hline 39.1 & 0.1559 & 0.0004 & 1.5384 & 0.0190 & 0.0717 & 0.0008 & 934 & 2 & 978 & 23 & 4 \\
\hline 40.1 & 0.1700 & 0.0018 & 1.7398 & 0.0351 & 0.0742 & 0.0011 & 1012 & 10 & 1048 & 31 & 3 \\
\hline 41.1 & 0.3238 & 0.0032 & 5.4235 & 0.1080 & 0.1210 & 0.0018 & 1808 & 16 & 1970 & 26 & 8 \\
\hline 42.1 & 0.5761 & 0.0059 & 17.0444 & 0.3426 & 0.2147 & 0.0032 & 2933 & 24 & 2947 & 24 & 0 \\
\hline 43.1 & 0.1759 & 0.0018 & 1.7682 & 0.0357 & 0.0730 & 0.0011 & 1045 & 10 & 1014 & 31 & -3 \\
\hline 44.1 & 0.1615 & 0.0016 & 1.6174 & 0.0323 & 0.0728 & 0.0011 & 965 & 9 & 1009 & 31 & 4 \\
\hline 45.1 & 0.1783 & 0.0025 & 1.8221 & 0.0405 & 0.0745 & 0.0011 & 1057 & 14 & 1055 & 30 & 0 \\
\hline 45.2 & 0.1820 & 0.0019 & 1.8952 & 0.0379 & 0.0751 & 0.0011 & 1078 & 10 & 1074 & 30 & 0 \\
\hline 46.1 & 0.1671 & 0.0017 & 1.6608 & 0.0328 & 0.0723 & 0.0011 & 996 & 9 & 994 & 31 & 0 \\
\hline 47.1 & 0.1920 & 0.0020 & 2.0667 & 0.0425 & 0.0769 & 0.0012 & 1132 & 11 & 1121 & 30 & -1 \\
\hline 48.1 & 0.1598 & 0.0020 & 1.5689 & 0.0350 & 0.0711 & 0.0012 & 956 & 11 & 961 & 33 & 0 \\
\hline 49.1 & 0.4788 & 0.0055 & 12.0899 & 0.2518 & 0.2184 & 0.0037 & 2522 & 24 & 2975 & 27 & 15 \\
\hline 50.1 & 0.1617 & 0.0016 & 1.5832 & 0.0315 & 0.0715 & 0.0011 & 966 & 9 & 971 & 31 & 0 \\
\hline 51.1 & 0.3341 & 0.0070 & 5.6617 & 0.1652 & 0.1301 & 0.0033 & 1858 & 34 & 2096 & 43 & 11 \\
\hline 52.1 & 0.1632 & 0.0009 & 1.6224 & 0.0202 & 0.0727 & 0.0008 & 974 & 5 & 1006 & 21 & 3 \\
\hline 53.1 & 0.1680 & 0.0007 & 1.6739 & 0.0194 & 0.0726 & 0.0008 & 1001 & 4 & 1002 & 24 & 0 \\
\hline 54.1 & 0.3632 & 0.0014 & 6.5888 & 0.0675 & 0.1313 & 0.0013 & 1997 & 7 & 2112 & 17 & 5 \\
\hline 55.1 & 0.1618 & 0.0007 & 1.5953 & 0.0158 & 0.0719 & 0.0007 & 967 & 4 & 982 & 21 & 1 \\
\hline 56.1 & 0.5312 & 0.0031 & 14.1589 & 0.1592 & 0.1895 & 0.0019 & 2746 & 13 & 2741 & 16 & 0 \\
\hline 57.1 & 0.1691 & 0.0010 & 1.6975 & 0.0242 & 0.0729 & 0.0010 & 1007 & 6 & 1011 & 28 & 0 \\
\hline 58.1 & 0.1846 & 0.0006 & 1.9247 & 0.0197 & 0.0757 & 0.0008 & 1092 & 3 & 1088 & 21 & 0 \\
\hline 59.1 & 0.1832 & 0.0010 & 1.9132 & 0.0207 & 0.0756 & 0.0007 & 1085 & 6 & 1085 & 20 & 0 \\
\hline 60.1 & 0.2181 & 0.0007 & 2.5069 & 0.0245 & 0.0831 & 0.0008 & 1272 & 4 & 1276 & 19 & 0 \\
\hline 61.1 & 0.1674 & 0.0012 & 1.6263 & 0.0204 & 0.0726 & 0.0008 & 998 & 7 & 1002 & 22 & 0 \\
\hline 62.1 & 0.1760 & 0.0006 & 1.7911 & 0.0176 & 0.0742 & 0.0007 & 1045 & 3 & 1048 & 20 & 0 \\
\hline 63.1 & 0.1801 & 0.0011 & 1.9283 & 0.0227 & 0.0786 & 0.0008 & 1068 & 6 & 1165 & 20 & 8 \\
\hline 64.1 & 0.5847 & 0.0018 & 16.6729 & 0.1607 & 0.2079 & 0.0020 & 2968 & 8 & 2896 & 16 & -2 \\
\hline 65.1 & 0.1366 & 0.0014 & 1.3332 & 0.0192 & 0.0725 & 0.0010 & 825 & 8 & 999 & 28 & 17 \\
\hline 66.1 & 0.3541 & 0.0036 & 5.8024 & 0.1014 & 0.1199 & 0.0026 & 1954 & 17 & 1954 & 37 & 0 \\
\hline 67.1 & 0.1670 & 0.0014 & 1.6945 & 0.0225 & 0.0735 & 0.0010 & 996 & 8 & 1027 & 28 & 3 \\
\hline 68.1 & 0.4287 & 0.0095 & 9.9853 & 0.5283 & 0.1978 & 0.0040 & 2300 & 43 & 2813 & 33 & 18 \\
\hline 69.1 & 0.1512 & 0.0010 & 1.3984 & 0.0210 & 0.0714 & 0.0010 & 908 & 6 & 969 & 29 & 6 \\
\hline 70.1 & 0.1899 & 0.0010 & 1.9995 & 0.0235 & 0.0768 & 0.0011 & 1121 & 6 & 1119 & 28 & 0 \\
\hline 71.1 & 0.1878 & 0.0010 & 1.9366 & 0.0221 & 0.0764 & 0.0011 & 1109 & 5 & 1107 & 28 & 0 \\
\hline 72.1 & 0.1596 & 0.0010 & 1.5828 & 0.0188 & 0.0728 & 0.0010 & 955 & 6 & 1009 & 28 & 5 \\
\hline 73.1 & 0.2414 & 0.0016 & 2.9443 & 0.0360 & 0.0892 & 0.0012 & 1394 & 9 & 1414 & 26 & 1 \\
\hline
\end{tabular}


Table 4 (continued)

\begin{tabular}{|c|c|c|c|c|c|c|c|c|c|c|c|}
\hline \multirow[t]{2}{*}{ Grain spot } & \multicolumn{6}{|c|}{ Radiogenic ratios } & \multicolumn{4}{|l|}{ Age (Ma) } & \multirow[t]{2}{*}{$\%$ disc } \\
\hline & ${ }^{206} \mathrm{~Pb} /{ }^{238} \mathrm{U}$ & \pm & ${ }^{207} \mathrm{~Pb} /{ }^{235} \mathrm{U}$ & \pm & ${ }^{207} \mathrm{~Pb} /{ }^{206} \mathrm{~Pb}$ & \pm & ${ }^{206} \mathrm{~Pb} /{ }^{238} \mathrm{U}$ & \pm & ${ }^{207} \mathrm{~Pb} /{ }^{206} \mathrm{~Pb}$ & \pm & \\
\hline 74.1 & 0.4774 & 0.0038 & 11.6930 & 0.1786 & 0.1824 & 0.0025 & 2516 & 17 & 2677 & 23 & 6 \\
\hline 75.1 & 0.1645 & 0.0055 & 1.5571 & 0.0645 & 0.0720 & 0.0028 & 982 & 31 & 986 & 78 & 0 \\
\hline 76.1 & 0.1653 & 0.0010 & 1.6355 & 0.0196 & 0.0722 & 0.0010 & 986 & 5 & 990 & 29 & 0 \\
\hline 77.1 & 0.1617 & 0.0020 & 1.6089 & 0.0294 & 0.0723 & 0.0010 & 966.4 & 11.2 & 993.1 & 28.7 & 3 \\
\hline
\end{tabular}

Note: Errors are 1-sigma.

because ${ }^{87} \mathrm{Sr} /{ }^{86} \mathrm{Sr}$ ratios commonly reported for both sequences are homogenous around 0.7075 (Alvarenga et al., 2007; Babinski et al., 2007; Misi et al., 2007; Kuchenbecker, 2011). However, as Sr residence time in oceans far exceeds this environment's water composition homogenization (Jones and Jenkyns, 2001), ${ }^{87} \mathrm{Sr} /{ }^{86} \mathrm{Sr}$ ratios of coeval marine carbonates are similar to global ocean and marginal seas $\mathrm{Sr}$ isotopic composition (Kusnetsov et al., 2012). The less altered ${ }^{87} \mathrm{Sr} /{ }^{86} \mathrm{Sr}$ ratios of Sete Lagoas Formation could be then used to correlate the unit to other carbonate successions and to constrain its depositional age.

$\mathrm{Sr}$ content of carbonate rocks is a fast and reliable way to track samples that have undergone post-depositional modification of its original isotopic composition (Halverson et al., 2007). ${ }^{87} \mathrm{Sr} /{ }^{86} \mathrm{Sr}$ ratios vs. Sr content plot (Fig. 7) of studied carbonates clearly shows that samples with less than $600 \mathrm{ppm}$ of $\mathrm{Sr}$ have the most radiogenic ratios (>0.7092; Table 2). That is the case of all analysed samples from basal sequence. Sections VS and AP have several portions of tectonic dolomitised carbonates that seem to have their original $\mathrm{Sr}$ composition leached during tectonism with incorporation of radiogenic Sr (Fig. 3). The ${ }^{87} \mathrm{Sr} /{ }^{86} \mathrm{Sr}$ ratios of such samples are probably not original and therefore will be discarded. Sample 11-PGL-33 from upper sequence also has a distinguishable radiogenic ${ }^{87} \mathrm{Sr} /{ }^{86} \mathrm{Sr}$ ratio $(0.708593 \pm 0.000076$.), but its $\mathrm{Sr}$ content is very high (2704 ppm; Table 2). However, a more careful analysis of the $\mathrm{Mn} / \mathrm{Sr}$ vs. $\mathrm{Mg} / \mathrm{Ca}$ diagram shows that this sample has an increase of the $\mathrm{Mn} / \mathrm{Sr}$ ratio linked to an increase of the $\mathrm{Mg} / \mathrm{Ca}$ ratio (Fig. 7). As the Sr/Ca vs. Mn content diagram does not exhibit any Mn incorporation on the carbonate composition during decreasing of $\mathrm{Sr} / \mathrm{Ca}$ ratio (Fig. 7) and the sample is directly above the partially dolomitised zone of the PGL section (Fig. 3), we again propose a tectonic fluid presence during alteration. This sample will also be discarded for $\mathrm{Sr}$ isotope chemostratigraphy.

All the remaining carbonate samples are from upper sequence sections. They all display $\mathrm{Mn} / \mathrm{Sr}, \mathrm{Fe} / \mathrm{Sr}, \mathrm{Ca} / \mathrm{Sr}$ and $\mathrm{Mg} / \mathrm{Ca}$ ratios lower than $0.12,1.10,380$ and 0.01 , respectively (Table 2 ), which suggest samples with original or little modified $\mathrm{Sr}$ isotopic record (Veizer et al., 1989; Fölling and Frimmel, 2002; Kusnetsov et al., 2013). Geochemical diagrams also show that these carbonates do not follow any alteration trend (Fig. 7). Their ${ }^{87} \mathrm{Sr} /{ }^{86} \mathrm{Sr}$ ratios vary between 0.7072 and 0.7079 , and the $\mathrm{Sr}$ enriched samples of sections BAU and PGL have ratios close to $0.7075-0.7076$ (Table 2). These values are in agreement with previously reported ${ }^{87} \mathrm{Sr} /{ }^{86} \mathrm{Sr}$ ratios of 0.7075 for the Sete Lagoas Formation (Alvarenga et al., 2007; Babinski et al., 2007; Misi et al., 2007; Kuchenbecker, 2011).

Again, trying to constrain an age for the Sete Lagoas Formation based on Sr "blind dating" is a hard task. Depending on the assumed reference curve of $\mathrm{Sr}$ isotopic composition of Neoproterozoic seawater, different age intervals could be assumed. If the curve presented by Halverson et al. (2010) is chosen, then a post-Marinoan age is required for the Bambuí Group. However, in other available Sr evolution curves are used (e.g., Jacobsen and Kaufman, 1999; Melezhik et al., 2001; Kusnetsov et al., 2013) then age constraints are only restricted to a large interval between 750 and 600 Ma for the deposition of the Sete Lagoas Formation. It means that this unit could be either post-Sturtian or post-Marinoan and the $\mathrm{Sr}$ isotope chemostratigraphy does not help solve the puzzle concerned to the age of the Bambuí Group. Therefore, it is necessary to look up into our geochronological data.

\subsection{Age constraining and implications for Bambuí Group}

Detailed stratigraphic sections from both sequences of the Sete Lagoas Formation help evaluate a possible unconformity inside the unit and estimate its depositional age. The age data point to the Araçuaí orogen as the source of the dated zircon grains, as most of the obtained ages are found in granitic rocks found therein. About $75 \%$ of the grains from sample 11-AP-05 presented ages between 630 and $584 \mathrm{Ma}$ (Table 3), resulting in a concordia age of $593 \pm 1.7$ Ma (Fig. 5). These data suggest that the sources of the grains are the igneous rocks from the G1 supersuite (630-585 Ma; Pedrosa-Soares et al., 2011b) of the Araçuaí Orogen magmatic arc, located to the east of the São Francisco craton (Fig. 1). Minor sources seem to be represented by collisional granites of the Araçuaí orogen, ranging in age from ca. 585 Ma to ca. $545 \mathrm{Ma}$ (Pedrosa-Soares et al., 2011b; Peixoto et al., 2015).

Sample 11-VS-13 showed different sources from section AP, with an important contribution from Mesoproterozoic rocks (Table 4; Fig. 6). Sources in the 1400-1050 Ma interval are unknown in the AraçuaíWest Congo Orogen. Similar populations were found in the Macaúbas Group (Babinski et al., 2012) and in the Espinhaço Supergroup (Valladares et al., 2004; Valeriano et al., 2004; Chemale et al., 2012), both located to the east of the craton, suggesting that this zircon population found in Sete Lagoas Formation could be reworked from these older units. The oldest Tonian ( $967 \mathrm{Ma}$ ) sources are probably the volcanic rocks and granites from Mayumbian and Zadinian Groups and Noqui granites, dated between $912 \pm 7 \mathrm{Ma}$ and $999 \pm 7 \mathrm{Ma}$ (Tack et al., 2001). The $873 \mathrm{Ma}$ zircons may come from the anorogenic granites of the northeastern Araçuaí orogen, dated at $875 \pm 9$ Ma (Silva et al., 2008). The source of the $\sim 656$ Ma peak may include plagiogranites of the Ribeirão da Folha ophiolite (Queiroga et al., 2007), the youngest intrusions of the Alkaline Province of Bahia State (Teixeira et al., 1997), sources in the magmatic arcs located in Ribeira belt (Tupinambá et al., 2012; Heilbron et al., 2013), and/or recycled sources containing zircon grains from the referred sources.

The geochronology of the upper sequence is represented by sample 11-PGL-PEL (Table 5). The source of the most important zircon population ( $625 \mathrm{Ma}-$ almost $70 \%$ of the dated grains; Fig. 6) is probably the G1 supersuite of the Araçuaí orogen (Pedrosa-Soares et al., 2011a, $2011 \mathrm{~b}$ ). The other important peak is $\sim 557 \mathrm{Ma}$ (about $27 \%$ of the grains) and its source may be the rocks from syn-collisional G2 supersuite. There are minor contributions from Archaean and Palaeoproterozoic sources from the basement of the São Francisco Craton. A few grains show ages younger than $550 \mathrm{Ma}$ that could be related to $\mathrm{Pb}$ loss due hydrothermal fluid percolation along detachment shears between the marl layers during tectonism. However, more precise geochronological analyses have to be done in order to confirm the younger ages obtained from a few zircon grains. In any case, the youngest and voluminous ( $\sim 27 \%$ of the dated grains) zircon population of $557 \mathrm{Ma}$ is the best estimate for the maximum depositional age of the Bambuí Group.

Our $\mathrm{U}-\mathrm{Pb}$ ages have some important implications for the Sete Lagoas Formation and the Bambuí Group, as they are significantly younger than those previously reported in the literature. The $557 \mathrm{Ma}$ zircon population strongly suggests that the sedimentation of most of the Bambui Group started in late Ediacaran times. The data also refute the hypothesis of a major gap of $\sim 130$ Ma between the sequences. The constant ${ }^{87} \mathrm{Sr} /$ 
Table 5

Summary of SHRIMP U-Pb zircon results for sample 11-PGL-PEL.

\begin{tabular}{|c|c|c|c|c|c|c|c|c|c|c|c|}
\hline \multirow[t]{2}{*}{ Grão. spot } & \multicolumn{6}{|c|}{ Radiogenic ratios } & \multicolumn{4}{|l|}{ Age (Ma) } & \multirow[t]{2}{*}{$\%$ disc } \\
\hline & ${ }^{206} \mathrm{~Pb} /{ }^{238} \mathrm{U}$ & \pm & ${ }^{207} \mathrm{~Pb} /{ }^{235} \mathrm{U}$ & \pm & ${ }^{207} \mathrm{~Pb} /{ }^{206} \mathrm{~Pb}$ & \pm & ${ }^{206} \mathrm{~Pb} /{ }^{238} \mathrm{U}$ & \pm & ${ }^{207} \mathrm{~Pb} /{ }^{206} \mathrm{~Pb}$ & \pm & \\
\hline GL 1.1 & 0.1115 & 0.0012 & 0.9548 & 0.0178 & 0.0623 & 0.0009 & 682 & 7 & 678 & 32 & 0 \\
\hline GL 1.2 & 0.0880 & 0.0010 & 0.7094 & 0.0163 & 0.0593 & 0.0012 & 543 & 6 & 574 & 42 & 5 \\
\hline GL 2.1 & 0.4063 & 0.0043 & 7.2757 & 0.1331 & 0.1294 & 0.0019 & 2087 & 25 & 2087 & 25 & -5 \\
\hline GL 3.1 & 0.0983 & 0.0010 & 0.8165 & 0.0162 & 0.0603 & 0.0010 & 605 & 6 & 607 & 35 & 0 \\
\hline GL 4.1 & 0.1037 & 0.0011 & 0.8708 & 0.0186 & 0.0610 & 0.0011 & 636 & 7 & 633 & 38 & 0 \\
\hline GL 5.1 & 0.1059 & 0.0012 & 0.9000 & 0.0172 & 0.0614 & 0.0010 & 649 & 7 & 649 & 34 & 0 \\
\hline GL 6.1 & 0.1308 & 0.0016 & 2.0435 & 0.0417 & 0.1139 & 0.0017 & 792 & 9 & 1864 & 27 & 57 \\
\hline GL 7.1 & 0.0962 & 0.0010 & 0.8072 & 0.0149 & 0.0608 & 0.0009 & 592 & 6 & 626 & 32 & 5 \\
\hline GL 8.1 & 0.1007 & 0.0010 & 0.8386 & 0.0159 & 0.0608 & 0.0010 & 618 & 6 & 626 & 34 & 1 \\
\hline GL 9.1 & 0.1025 & 0.0010 & 0.8560 & 0.0159 & 0.0609 & 0.0009 & 629 & 6 & 630 & 33 & 0 \\
\hline GL 10.1 & 0.1054 & 0.0011 & 0.8893 & 0.0185 & 0.0624 & 0.0011 & 646 & 6 & 683 & 38 & 5 \\
\hline GL 11.1 & 0.0989 & 0.0011 & 0.8251 & 0.0193 & 0.0602 & 0.0013 & 608 & 7 & 606 & 45 & 0 \\
\hline GL 12.1 & 0.1039 & 0.0012 & 0.8769 & 0.0170 & 0.0611 & 0.0009 & 637 & 7 & 637 & 33 & 0 \\
\hline 1.1 & 0.1024 & 0.0009 & 0.8547 & 0.0115 & 0.0607 & 0.0005 & 629 & 5 & 621 & 17 & -1 \\
\hline 2.1 & 0.1013 & 0.0009 & 0.8602 & 0.0117 & 0.0613 & 0.0005 & 622 & 5 & 644 & 17 & 3 \\
\hline 3.1 & 0.0911 & 0.0008 & 0.7618 & 0.0107 & 0.0606 & 0.0005 & 562 & 5 & 619 & 19 & 9 \\
\hline 4.1 & 0.1021 & 0.0009 & 0.8583 & 0.0114 & 0.0608 & 0.0005 & 627 & 5 & 624 & 17 & 0 \\
\hline 5.1 & 0.1038 & 0.0009 & 0.8766 & 0.0115 & 0.0609 & 0.0005 & 637 & 5 & 629 & 17 & -1 \\
\hline 6.1 & 0.1048 & 0.0009 & 0.8845 & 0.0121 & 0.0612 & 0.0005 & 642 & 5 & 641 & 17 & 0 \\
\hline 7.1 & 0.1027 & 0.0009 & 0.8576 & 0.0118 & 0.0610 & 0.0005 & 630 & 5 & 633 & 19 & 0 \\
\hline 8.1 & 0.5868 & 0.0065 & 21.6644 & 0.4656 & 0.2742 & 0.0041 & 3325 & 23 & 3325 & 23 & 10 \\
\hline 9.1 & 0.1022 & 0.0010 & 0.8652 & 0.0118 & 0.0608 & 0.0005 & 627 & 6 & 625 & 17 & 0 \\
\hline 10.1 & 0.0924 & 0.0008 & 0.7646 & 0.0108 & 0.0600 & 0.0006 & 570 & 5 & 596 & 20 & 4 \\
\hline 11.1 & 0.0769 & 0.0011 & 0.6550 & 0.0131 & 0.0605 & 0.0005 & 478 & 7 & 616 & 19 & 22 \\
\hline 12.1 & 0.0985 & 0.0009 & 0.8148 & 0.0109 & 0.0602 & 0.0005 & 606 & 5 & 605 & 18 & 0 \\
\hline 13.1 & 0.0939 & 0.0009 & 0.7842 & 0.0117 & 0.0604 & 0.0005 & 578 & 5 & 611 & 19 & 5 \\
\hline 14.1 & 0.1007 & 0.0008 & 0.8357 & 0.0114 & 0.0606 & 0.0003 & 618 & 5 & 619 & 12 & 0 \\
\hline 15.1 & 0.0986 & 0.0009 & 0.8278 & 0.0113 & 0.0610 & 0.0004 & 606 & 5 & 633 & 13 & 4 \\
\hline 16.1 & 0.0956 & 0.0008 & 0.7959 & 0.0111 & 0.0601 & 0.0004 & 588 & 5 & 602 & 14 & 2 \\
\hline 17.1 & 0.1073 & 0.0010 & 0.9109 & 0.0129 & 0.0617 & 0.0004 & 657 & 6 & 657 & 13 & 0 \\
\hline 18.1 & 0.1038 & 0.0008 & 0.8740 & 0.0116 & 0.0607 & 0.0003 & 637 & 5 & 622 & 11 & -2 \\
\hline 19.1 & 0.1084 & 0.0012 & 0.9243 & 0.0144 & 0.0618 & 0.0004 & 663 & 7 & 661 & 15 & 0 \\
\hline 20.1 & 0.1024 & 0.0008 & 0.8638 & 0.0114 & 0.0609 & 0.0003 & 628 & 5 & 629 & 12 & 0 \\
\hline 21.1 & 0.1021 & 0.0008 & 0.8550 & 0.0109 & 0.0609 & 0.0003 & 627 & 5 & 629 & 11 & 0 \\
\hline 22.1 & 0.0898 & 0.0008 & 0.7284 & 0.0102 & 0.0604 & 0.0004 & 554 & 5 & 612 & 13 & 9 \\
\hline 23.1 & 0.0716 & 0.0012 & 0.5682 & 0.0126 & 0.0572 & 0.0004 & 446 & 7 & 495 & 17 & 10 \\
\hline 24.1 & 0.1016 & 0.0008 & 0.8531 & 0.0111 & 0.0610 & 0.0003 & 624 & 5 & 632 & 12 & 1 \\
\hline 25.1 & 0.0923 & 0.0008 & 0.7663 & 0.0106 & 0.0599 & 0.0004 & 569 & 5 & 594 & 14 & 4 \\
\hline 26.1 & 0.1060 & 0.0009 & 0.8941 & 0.0118 & 0.0612 & 0.0003 & 649 & 5 & 640 & 11 & -1 \\
\hline 27.1 & 0.1046 & 0.0005 & 0.8714 & 0.0096 & 0.0607 & 0.0006 & 641 & 3 & 621 & 21 & -3 \\
\hline 28.1 & 0.0903 & 0.0009 & 0.7405 & 0.0120 & 0.0598 & 0.0006 & 557 & 6 & 589 & 22 & 5 \\
\hline 29.1 & 0.0991 & 0.0005 & 0.8363 & 0.0095 & 0.0611 & 0.0006 & 609 & 3 & 636 & 21 & 4 \\
\hline 30.1 & 0.1036 & 0.0006 & 0.8701 & 0.0104 & 0.0611 & 0.0006 & 635 & 4 & 638 & 20 & 0 \\
\hline 31.1 & 0.0892 & 0.0005 & 0.7397 & 0.0095 & 0.0599 & 0.0006 & 551 & 3 & 592 & 23 & 7 \\
\hline 32.1 & 0.1025 & 0.0005 & 0.8608 & 0.0096 & 0.0609 & 0.0006 & 629 & 3 & 629 & 20 & 0 \\
\hline 33.1 & 0.0955 & 0.0005 & 0.8052 & 0.0091 & 0.0609 & 0.0006 & 588 & 3 & 628 & 21 & 6 \\
\hline 34.1 & 0.1074 & 0.0007 & 0.8942 & 0.0106 & 0.0611 & 0.0006 & 658 & 4 & 636 & 21 & -3 \\
\hline 35.1 & 0.1026 & 0.0005 & 0.8647 & 0.0094 & 0.0615 & 0.0006 & 630 & 3 & 649 & 20 & 3 \\
\hline 36.1 & 0.0940 & 0.0006 & 0.7908 & 0.0095 & 0.0600 & 0.0006 & 579 & 3 & 597 & 21 & 3 \\
\hline 37.1 & 0.1005 & 0.0005 & 0.8343 & 0.0100 & 0.0605 & 0.0006 & 617 & 3 & 617 & 21 & 0 \\
\hline 38.1 & 0.1051 & 0.0005 & 0.8905 & 0.0095 & 0.0611 & 0.0006 & 644 & 3 & 635 & 20 & -1 \\
\hline 39.1 & 0.1030 & 0.0006 & 0.8737 & 0.0103 & 0.0616 & 0.0006 & 632 & 4 & 653 & 20 & 3 \\
\hline 40.1 & 0.0909 & 0.0009 & 0.7356 & 0.0123 & 0.0589 & 0.0009 & 561 & 6 & 559 & 33 & 0 \\
\hline 41.1 & 0.1053 & 0.0008 & 0.8883 & 0.0104 & 0.0613 & 0.0007 & 645 & 5 & 643 & 26 & 0 \\
\hline 42.1 & 0.0923 & 0.0007 & 0.7958 & 0.0094 & 0.0626 & 0.0007 & 569 & 4 & 689 & 26 & 17 \\
\hline 43.1 & 0.1042 & 0.0009 & 0.9118 & 0.0123 & 0.0630 & 0.0008 & 639 & 5 & 704 & 27 & 9 \\
\hline 44.1 & 0.1020 & 0.0010 & 0.8564 & 0.0112 & 0.0608 & 0.0008 & 626 & 6 & 627 & 27 & 0 \\
\hline 45.1 & 0.0934 & 0.0010 & 0.7626 & 0.0120 & 0.0594 & 0.0008 & 575 & 6 & 576 & 28 & 0 \\
\hline 46.1 & 0.1047 & 0.0010 & 0.8847 & 0.0113 & 0.0613 & 0.0007 & 642 & 6 & 643 & 26 & 0 \\
\hline 47.1 & 0.0852 & 0.0013 & 0.6330 & 0.0153 & 0.0599 & 0.0017 & 527 & 8 & 595 & 61 & 11 \\
\hline 48.1 & 0.0905 & 0.0009 & 0.7561 & 0.0113 & 0.0605 & 0.0008 & 559 & 5 & 615 & 29 & 9 \\
\hline 49.1 & 0.1003 & 0.0009 & 0.8316 & 0.0115 & 0.0606 & 0.0009 & 616 & 5 & 618 & 30 & 0 \\
\hline 50.1 & 0.1054 & 0.0009 & 0.8869 & 0.0109 & 0.0614 & 0.0007 & 646 & 5 & 646 & 26 & 0 \\
\hline 51.1 & 0.0996 & 0.0008 & 0.8366 & 0.0100 & 0.0612 & 0.0007 & 612 & 5 & 640 & 26 & 4 \\
\hline 52.1 & 0.2266 & 0.0025 & 4.6865 & 0.0707 & 0.1524 & 0.0018 & 1317 & 13 & 2368 & 21 & 44 \\
\hline 53.1 & 0.0941 & 0.0003 & 0.7836 & 0.0057 & 0.0606 & 0.0004 & 580 & 2 & 619 & 13 & 6 \\
\hline 54.1 & 0.1018 & 0.0002 & 0.8635 & 0.0044 & 0.0614 & 0.0003 & 625 & 1 & 647 & 10 & 3 \\
\hline 55.1 & 0.0984 & 0.0006 & 0.8269 & 0.0072 & 0.0610 & 0.0003 & 605 & 4 & 632 & 12 & 4 \\
\hline 56.1 & 0.0969 & 0.0003 & 0.8197 & 0.0048 & 0.0615 & 0.0003 & 596 & 2 & 651 & 10 & 8 \\
\hline 57.1 & 0.0974 & 0.0002 & 0.8139 & 0.0048 & 0.0612 & 0.0004 & 599 & 1 & 639 & 12 & 6 \\
\hline 58.1 & 0.1002 & 0.0003 & 0.8402 & 0.0052 & 0.0605 & 0.0003 & 616 & 1 & 616 & 12 & 0 \\
\hline 59.1 & 0.0996 & 0.0003 & 0.8388 & 0.0046 & 0.0612 & 0.0003 & 612 & 2 & 640 & 11 & 4 \\
\hline 60.1 & 0.1053 & 0.0004 & 0.8886 & 0.0091 & 0.0613 & 0.0006 & 645 & 3 & 646 & 19 & 0 \\
\hline 61.1 & 0.0926 & 0.0003 & 0.7584 & 0.0048 & 0.0596 & 0.0004 & 571 & 2 & 582 & 13 & 2 \\
\hline
\end{tabular}


Table 5 (continued)

\begin{tabular}{|c|c|c|c|c|c|c|c|c|c|c|c|}
\hline \multirow[t]{2}{*}{ Grão. spot } & \multicolumn{6}{|c|}{ Radiogenic ratios } & \multicolumn{4}{|l|}{ Age (Ma) } & \multirow[t]{2}{*}{$\%$ disc } \\
\hline & ${ }^{206} \mathrm{~Pb} /{ }^{238} \mathrm{U}$ & \pm & ${ }^{207} \mathrm{~Pb} /{ }^{235} \mathrm{U}$ & \pm & ${ }^{207} \mathrm{~Pb} /{ }^{206} \mathrm{~Pb}$ & \pm & ${ }^{206} \mathrm{~Pb} /{ }^{238} \mathrm{U}$ & \pm & ${ }^{207} \mathrm{~Pb} /{ }^{206} \mathrm{~Pb}$ & \pm & \\
\hline 62.1 & 0.0816 & 0.0008 & 0.6166 & 0.0102 & 0.0575 & 0.0006 & 506 & 4 & 504 & 22 & 0 \\
\hline 63.1 & 0.0984 & 0.0005 & 0.8153 & 0.0063 & 0.0606 & 0.0003 & 605 & 3 & 620 & 12 & 2 \\
\hline 64.1 & 0.1035 & 0.0003 & 0.8704 & 0.0047 & 0.0610 & 0.0003 & 635 & 2 & 633 & 11 & 0 \\
\hline 65.1 & 0.0977 & 0.0003 & 0.8125 & 0.0051 & 0.0603 & 0.0004 & 601 & 2 & 610 & 14 & 1 \\
\hline
\end{tabular}

Note: Errors are 1-sigma.

${ }^{86} \mathrm{Sr}$ ratios $(\sim 0.7075)$ reported for both sequences is another evidence that this gap is much shorter or does not exist, as already discussed by Caxito et al. (2012). Therefore, the youngest voluminous zircon population ( $557 \mathrm{Ma})$ sets the maximum depositional age for the Sete Lagoas Formation and most of the Bambui Group. This age is consistent with the recently found index fossil Cloudina in this unit (Warren et al., 2014), which is thought to have lived between 550 and $543 \mathrm{Ma}$ (Grotzinger et al., 2000).
If there is a major gap of sedimentation within the Sete Lagoas Formation, it is positioned between the basal cap carbonate sequence and the succeeding carbonates that preserve higher $\delta^{13} \mathrm{C}$ values of around $0 \%$. No erosive unconformity surface is known from here. In this work, no geochronological data were obtained from the basal cap carbonates with $\delta^{13} \mathrm{C}$ values as low as $-4.5 \%$, which would be equivalent of the one previously dated at $740 \pm 22 \mathrm{Ma}$ (Babinski et al., 2007).

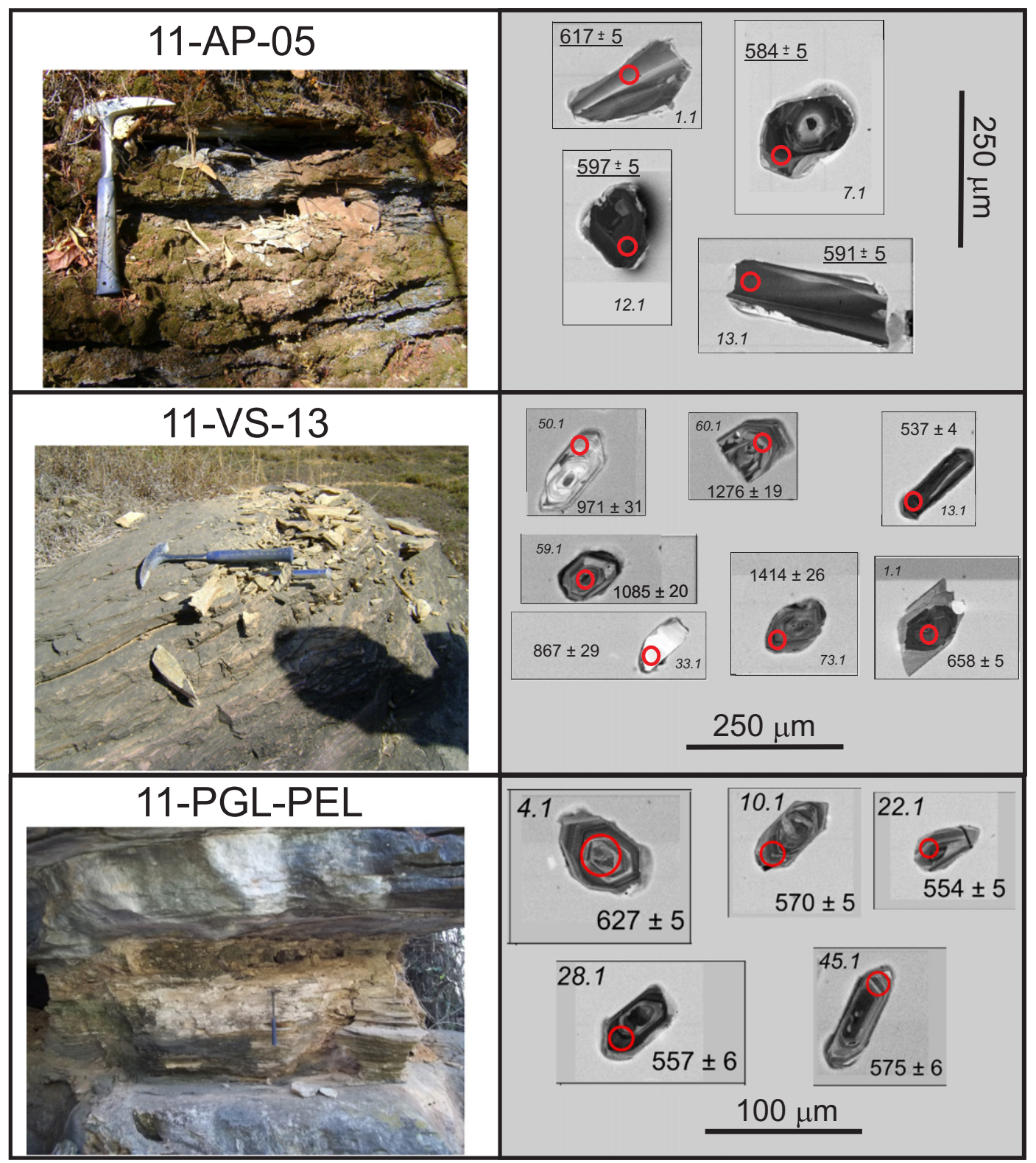

Fig. 4. Field images of the marl samples (hammer is $\sim 30 \mathrm{~cm}$ tall) and their respective cathodoluminescence images of the retrieved zircon grains. 

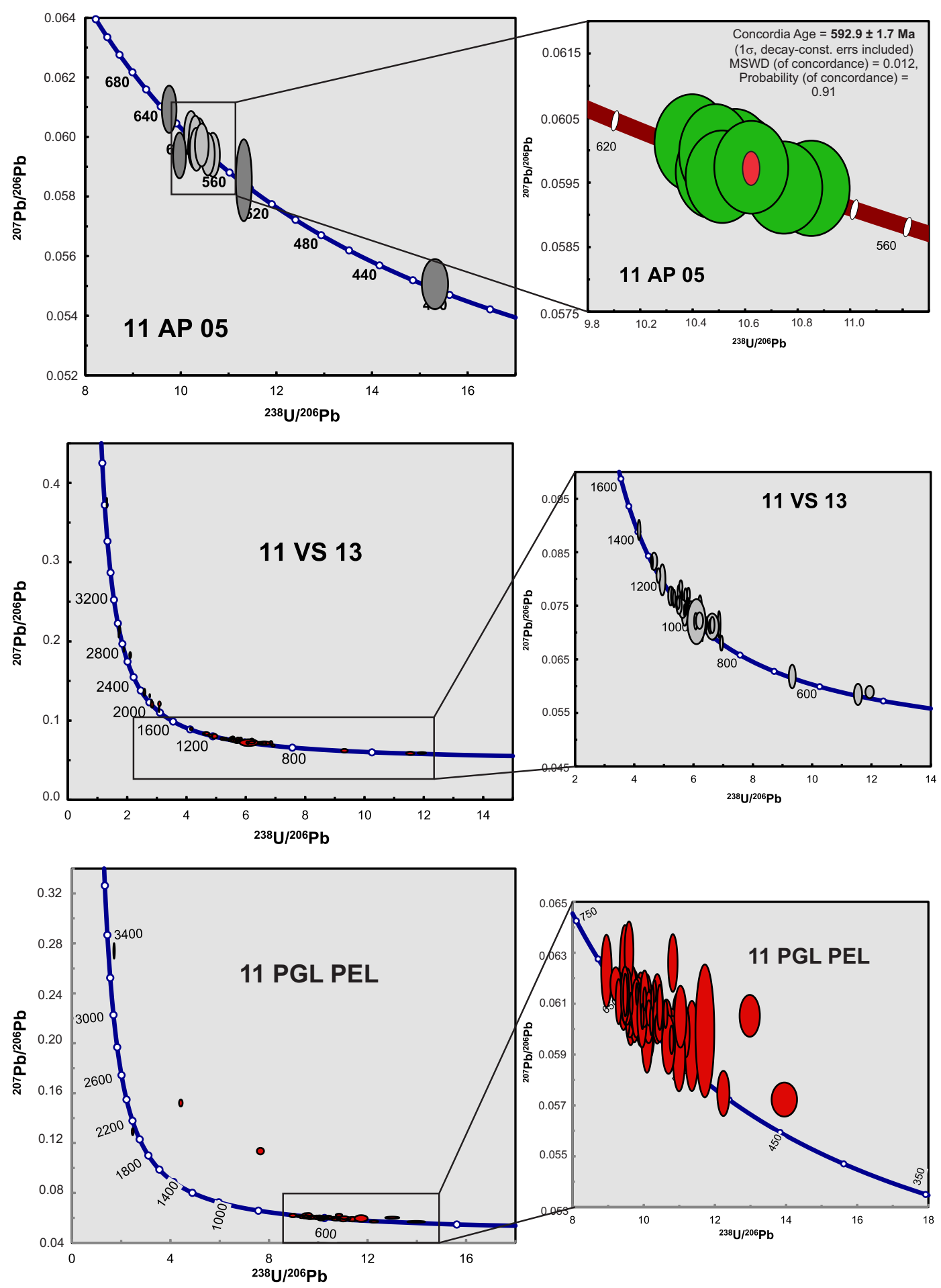

Fig. 5. Tera and Wasserburg (1972) concordia diagram obtained for the marl samples.

Other important implications of the obtained ages concern the tectonic framework of the São Francisco Craton during the deposition of the Bambuí Group. The maximum depositional age around $560 \mathrm{Ma}$ suggests that most of the Sete Lagoas Formation was deposited after the closure of the Adamastor Ocean. At that time, the Araçuaí-West Congo orogen already existed to the east of the São Francisco Craton. This suggests that the marine units of the Bambuí Group were probably deposited in a restricted sea, confined by the marginal belts surrounding the São Francisco Craton in the late Ediacaran. This scenario is consistent with our geochronological data that points to the post-collisional supersuites of the Araçuaí Belt acting as sources to the Sete Lagoas
Formation. In addition, if the sources of the 1400-900 Ma zircon grains in the Sete Lagoas Formation are from the Macaúbas Group sediments, this unit was already partially exhumed within the margin of the orogen. Interestingly, the basal sample (11-VS-13) shows a wide distribution of detrital zircon ages (Fig. 6) whose rounded morphology suggests some degree of sedimentary reworking (Fig. 4). The distribution of ages for this sample resembles those obtained for the glacial deposits of Macaúbas Group (Babinski et al., 2012). In contrast, the sample collected in the upper unit provides only Ediacaran peaks of zircon ages (Fig. 6), which match the different generations of granites mapped in the Araçuaí Belt (Pedrosa-Soares et al., 2011a, 2011b). This source 


\section{1-VS-13}

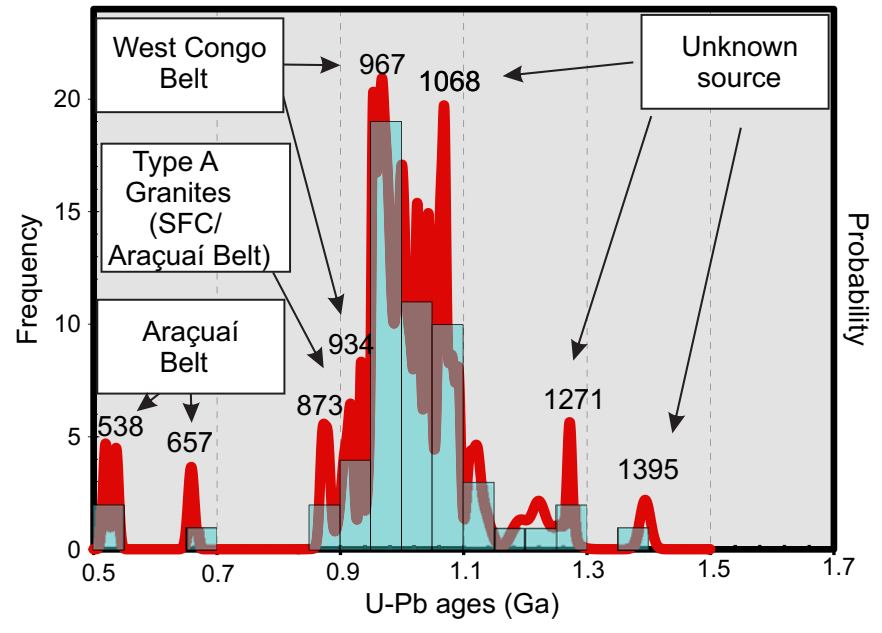

11-PGL-PEL

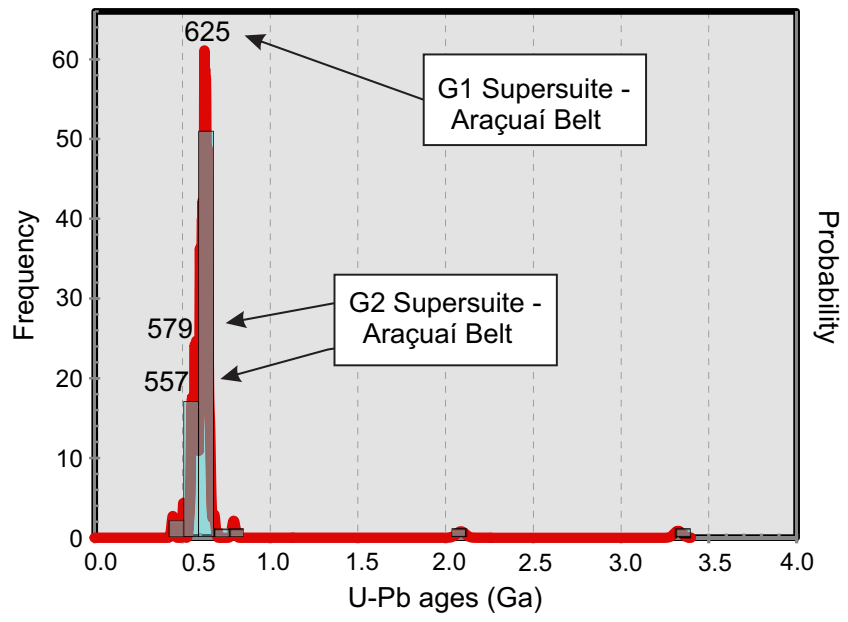

Fig. 6. Histogram obtained with $\mathrm{U}-\mathrm{Pb}$ ages from detrital zircons retrieved from samples 11-VS-13 and 11-PGL-PEL. Only ages within the 90-110\% concordance interval were considered.

change suggests that the filling of the Bambuí basin is, at least partially, coeval with uplifting of the Araçuaí Belt.

The restricted basin scenario proposed here requires additional study. However, some evidence seems to support a confined epeiric sea. The presence of Cloudina in the Sete Lagoas Formation suggests ocean connectivity among coeval intracratonic basins of South America, Africa and Antarctica at the Ediacaran-Cambrian boundary (Warren et al., 2014). However, unlike the other Ediacaran units, the Sete Lagoas Formation yields ${ }^{87} \mathrm{Sr} /{ }^{86} \mathrm{Sr}$ ratios lower than those expected when compared to Neoproterozoic seawater $\mathrm{Sr}$ evolution curves. While it displays ratios around 0.7075 , the curves presuppose ratios higher than 0.7080 (Jacobsen and Kaufman, 1999; Melezhik et al., 2001; Halverson et al., 2010; Kusnetsov et al., 2013). Other South American carbonate Cloudina-bearing successions such as the Corumbá and the Arroyo del Soldado groups display ${ }^{87} \mathrm{Sr} /{ }^{86} \mathrm{Sr}$ ratios higher than 0.7080 (Boggiani, 1998; Gaucher et al., 2004; Boggiani et al., 2010). This probably means that these two units were thoroughly linked to the global ocean, whereas the Bambuí Group was not. This also suggests that the connections of the São Francisco Craton epeiric sea with other intracratonic Ediacaran marine basins were possibly intermittent and short lived. This prevented constant and significant mixing of the San Francisco Craton seawaters with others coming from external basins, resulting in different $\mathrm{Sr}$ isotope ratios. In fact, the Cloudina specimens described in the Sete Lagoas Formation were found on carbonates with $\delta^{13} \mathrm{C}$ of around $0 \%$ and from the top of the basal sequence (Warren et al., 2014). So the occurrence of the fossil precedes the abrupt shift on $\mathrm{C}$ isotope values close to the sequence boundary. It is possible that this marked positive excursion of the $C$ isotope values sets the changing of an intracontinental basin sporadically linked to other basins by an proto-Gondwana seaway to an restricted basin with $\delta^{13} \mathrm{C}$ values much higher than those of the Corumbá and the Arroyo del Soldado groups (Gaucher et al., 2004; Boggiani et al., 2010) that could not be explained only by bioproductivity increase or organic matter burial. The hypothesis of fermentation-related methanogenesis and direct reduction of $\mathrm{CO}_{2}$ in a restricted environment has to be considered to explain $\delta^{13} \mathrm{C}$ values as high as $+14 \%$. The $\mathrm{Sr}$ content of the upper sequence carbonates (as high as 3500 ppm) are also flagrantly higher than those described for Ediacaran units as well as than those considered for the Sr seawater evolution curve calibration (Jacobsen and Kaufman, 1999; Melezhik et al., 2001; Halverson et al., 2010; Kusnetsov et al., 2013). This could be a result of enhanced evaporation due to the basin confinement, a process that could also lead to higher $\delta^{13} \mathrm{C}$ values (Frimmel, 2010). It is worth mentioning that the debate of the meaning of the chemostratigraphy data of the Bambuí Group is still speculative and needs more detailed studies.

Other problems concerning an Ediacaran age for the Sete Lagoas Formation regard the tectonic relationship between the deposition of the Bambuí Group and the geological evolution of the San Francisco Craton marginal belts. A large dataset, including field relations, distribution and nature of sedimentary rocks, seismic and gravimetric data, suggests that the Bambuí Group was deposited in a foreland basin, with flexural subsidence mainly induced by crustal loading by the Brasília Belt (Martins-Neto et al., 2001; Coelho et al., 2008). The timing of mountain building and sediment accumulation along the foreland is constrained by data from the magmatic units within the belt and detrital zircons in the sediments. Collisional ages in the Brasillia Belt obtained mostly from its prominent granitic magmatism suggest that the peak of collision has occurred at $\sim 620$ Ma (e.g., Pimentel et al., 1999; Pimentel et al., 2011). Recent provenance studies based on zircon dating in sedimentary units at the western border of the São Francisco Craton show ages older than 930 Ma for the Vazante Group, similar to the pattern observed for the diamictites (Rodrigues et al., 2012). Thus, sedimentary successions deposited at the base of the Bambuí Group seem to pre-date the orogeny buildup. Abundant Neoproterozoic ages, which would ascertain a Brasília Belt provenance, are found only in the Três Marias Formation, the uppermost unit of the Bambuí Group (Pimentel et al., 2001; Pimentel et al., 2011). Our new data provide better temporal constraints to these events, since it places a maximum depositional age for the base of the Bambuí Group at around 560 Ma, suggesting that foreland sedimentation in the craton has started later than previously thought. In fact, our data shows that the Sete Lagoas Formation sedimentation is coeval with the construction of the Araçuaí Belt and may have been strongly influenced by it (Pedrosa-Soares et al., 2011a, 2011b). Nevertheless, the time span between the supposed flexural subsidence ( 620 Ma; Pimentel et al., 1999; Pimentel et al., 2011) and the start of the sedimentation $(\sim 560 \mathrm{Ma})$ is too long and problematic. Other subsidence mechanisms might have occurred or some geochronological piece of the puzzle is missing. This also is valid to explain why the Bambuí Group is deformed on its western border as the Brasília orogen would be in its collapse phase during the late Ediacaran (Pimentel et al., 1999).

\subsection{U-Pb dating vs. Sr "blind dating": some considerations}

The U-Pb data of detrital zircons and $\mathrm{Sr}$ isotope data from carbonates clearly provides different age constrains for the Sete Lagoas Formation. The commonly reported ${ }^{87} \mathrm{Sr} /{ }^{86} \mathrm{Sr}$ ratios around 0.7075 for the unit (Alvarenga et al., 2007; Misi et al., 2007; Kuchenbecker, 2011; this work) are significantly less radiogenic than those expected for the end of Ediacaran according to several $\mathrm{Sr}$ isotope composition evolution curves and compilations (Jacobsen and Kaufman, 1999; Melezhik et al., 

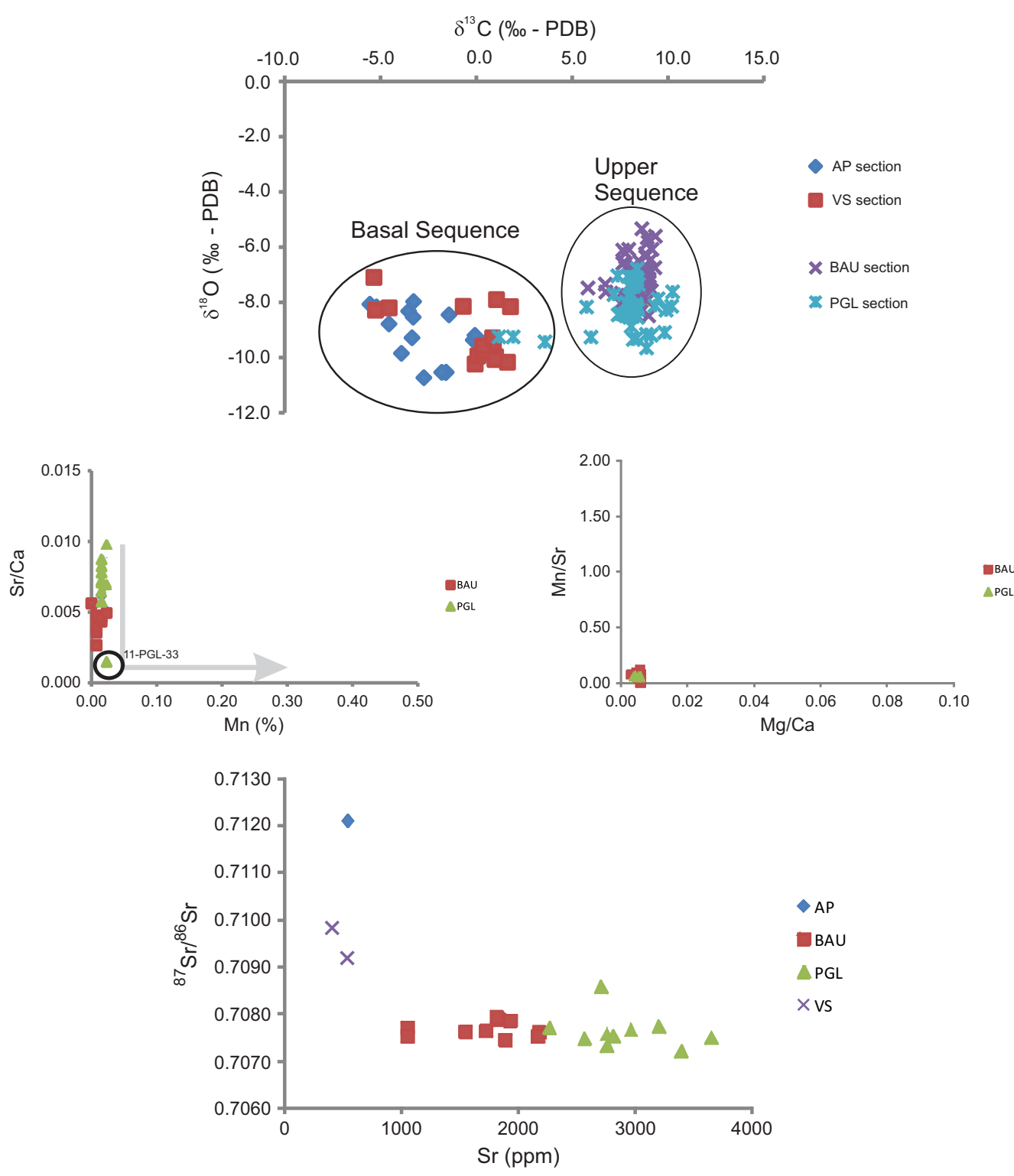

Fig. 7. $\delta^{13} \mathrm{C}$ vs. $\delta^{18} \mathrm{O}, \mathrm{Mn}(\%)$ vs. $\mathrm{Sr} / \mathrm{Ca}, \mathrm{Mg} / \mathrm{Ca}$ vs. Mn/Sr and $\mathrm{Sr}(\mathrm{ppm})$ vs. ${ }^{87} \mathrm{Sr} /{ }^{86} \mathrm{Sr}$ geochemical diagrams of the carbonates of SLF.

2001; Halverson et al., 2010; Kusnetsov et al., 2013). ${ }^{87} \mathrm{Sr} /{ }^{86} \mathrm{Sr}$ ratios higher than 0.7080 were expected for a carbonate succession younger than $560 \mathrm{Ma}$. Additionally, other Cloudina-bearing carbonate successions in South America also display ratios higher than 0.7080 (Boggiani, 1998; Gaucher et al., 2004; Boggiani et al., 2010).

As previously discussed, the tectonic framework of the São Francisco Craton during the Ediacaran could explain such discrepancy. During that period, the craton was almost completely surrounded by fold belts and was located at the inner parts of the western Gondwana continent (Pedrosa-Soares et al., 2011a, 2011b; Alkmin and Martins-Neto, 2012). Such a scenario strongly suggests a restricted marine basin. The presence of the index fossil Cloudina suggests connection with other Ediacaran marine basins, but the non-radiogenic $\mathrm{Sr}$ ratios show that such connection was possibly intermittent and short lived, preventing efficient mixing of the San Francisco Craton seawaters with others coming from external basins.

One possibility to explain the $\mathrm{Sr}$ isotopic discrepancy is that this restricted sea could possibly have received large amounts of riverine freshwater and little external seawater, implying in a different isotope evolution from contemporaneous global ocean. It is known that the riverine influx is the main factor controlling the Sr budget on modern oceans (Goldstein and Jacobsen, 1987; Palmer and Edmond, 1989), and there is no reason to believe otherwise for restricted environments. However, most of modern rivers have ${ }^{87} \mathrm{Sr} /{ }^{86} \mathrm{Sr}$ ratios higher than the modern oceans (Goldstein and Jacobsen, 1987; Palmer and Edmond, 1992; Gaillardet et al., 1997), and thus is expected that a restricted basin should display higher ratios than the contemporaneous global ocean. But there are some exceptions. The São Francisco Craton epeiric sea is most likely to have received riverine freshwater draining the uplifted areas with typical lithology assembly from mobile belts (quartzites, pelites and carbonates, granites and trapped basement rocks). Modern rivers draining similar areas are usually $\mathrm{Sr}$ enriched and have lower ${ }^{87} \mathrm{Sr} /{ }^{86} \mathrm{Sr}$ ratios than contemporaneous global ocean due to preferential carbonate leaching on highland areas (Palmer and Edmond, 1992). If a similar process occurred in the São Francisco Craton, the continuously delivering of freshwaters rich in $\mathrm{Sr}$ and with low ${ }^{87} \mathrm{Sr} /{ }^{86} \mathrm{Sr}$ ratios may have progressively lowered the ratio of the restrict sea. Although our geochronological data suggest that the Araçuaí Orogen, with no significant older carbonate successions, is the main source of the Bambuí Group in the southeast of the San Francisco Craton, at a regional scale the basin might have received waters from rivers draining areas where ancient carbonates were exposed. Examples of 
carbonate successions older than the Sete Lagoas Formation and with lower ${ }^{87} \mathrm{Sr} /{ }^{86} \mathrm{Sr}$ ratios are the Paranoá Group (Alvarenga et al., 2007) and the Vazante Group (Azmy et al., 2001) in western Brasília Belt. To evaluate if carbonate weathering contribution to the $\mathrm{Sr}$ ratios of the Bambuí Group was more important than silicate weathering, additional studies using other proxies are necessary, as the current database is insufficient.

Although our claimed scenario seems possible, recently published studies have shown that the $\mathrm{Sr}$ isotope composition of modern marginal and inland seas barely differ from the global ocean (Kusnetsov et al., 2012). The case of the Black Sea is the most intriguing, because its seawater dilution by riverine runoff is as high as 50 to $70 \%$, and could be somewhat similar to the Bambuí basin. However, two statements must be addressed: (i) the Black Sea is often filled with external marine water (Kusnetsov et al., 2012) and data from the fossil record and Sr isotopes suggest short lived and inefficient external water mixing in the São Francisco Craton; and (ii) values of riverine ${ }^{87} \mathrm{Sr} /{ }^{86} \mathrm{Sr}$ ratios delivered to the Black Sea are unknown. Curiously, the only value measured (not inferred) is 0.7127 (Krabbenhoft et al., 2010) which is higher than the world's riverine average delivered to oceans. This would imply in a $\mathrm{Sr}$ composition evolution of the Black Sea similar to that of the global ocean.

The cause of the lower ${ }^{87} \mathrm{Sr} /{ }^{86} \mathrm{Sr}$ ratios of the Sete Lagoas Formation notwithstanding, the fact is that they clearly disagree with our $\mathrm{U}-\mathrm{Pb}$ data on detrital zircons and the fossil assemblage of the unit. Other examples of such discrepancy are the Lantian Formation and Doushantuo Formation in South China. The Ediacaran upper unit of the Lantian Formation has ${ }^{87} \mathrm{Sr} /{ }^{86} \mathrm{Sr}$ ratios higher than 0.71 that strongly differs from the contemporaneous global ocean (Zhao et al., 2009). Anomalously high ${ }^{87} \mathrm{Sr} /{ }^{86} \mathrm{Sr}$ ratios $(\sim 0.71)$ are also reported for the Doushantuo Formation (Ohno et al., 2008), deposited between 635 and $551 \mathrm{Ma}$ (Condon et al., 2005). In both cases, the large disturbance in $\mathrm{Sr}$ composition of the ancient seawaters was attributed to local processes rather than to a global one. Frimmel (2009) proposed that these local variations were common in the Ediacaran when near-shore basins were flooded with continental freshwater with little exchange with global seawaters. The restriction of the marine basin in which the Bambuí Group was deposited contradicts an important premise for worldwide correlations using isotope chemostratigraphy (Melezhik et al., 2001). The C and Sr composition of the carbonates of the Sete Lagoas Formation probably reflects the composition of the former restricted seawaters rather than the composition of the global contemporaneous ocean. We therefore recommend caution on correlating the Sete Lagoas Formation and the Bambuí Group to other carbonate successions worldwide by using isotope chemostratigraphy. It is also recommended to use extreme caution on strontium "blind dating", especially in Ediacaran carbonate successions. $\mathrm{U}-\mathrm{Pb}$ dating on detrital zircon grains is a more reliable tool for age constraining and tracing the tectonic setting (Cawood et al., 2012). If dating of detrital minerals is not possible, the Sr blind dating should be performed very carefully, analysing the tectonic framework in which the carbonate succession was deposited and checking different Sr evolution curves for age constraining.

\section{Conclusions}

The $\mathrm{C}$ and $\mathrm{Sr}$ isotope and the $\mathrm{U}-\mathrm{Pb}$ geochronological data obtained in this work provided a new insight on the depositional age and sedimentary evolution of the Sete Lagoas Formation. Such data were obtained on sections from the upper sequence of the unit composed of dark carbonates with highly positive $\delta^{13} \mathrm{C}$ values $(>+6 \%$ ) and from the basal sequence composed of carbonates with $\delta^{13} \mathrm{C}$ values around $0 \%$, stratigraphically above the basal cap carbonates.

Marl samples from AP and PGL sections (basal and upper sequence respectively) provided detrital zircon grains with $\mathrm{U}-\mathrm{Pb}$ ages mainly ranging between 625 and $550 \mathrm{Ma}$. These data strongly suggest that the Araçuaí orogen, located east of the São Francisco Craton, was a sedimentary source acting during the deposition of the Sete Lagoas Formation in the studied area. Sample 11-VS-13 displayed several zircon populations with dominant ages between 1270 and $870 \mathrm{Ma}$ that also suggest the Araçuaí-West Congo Orogen as the main source. The similarity of these populations to those found on the Macaúbas Group (Araçuaí Belt) suggests that the sediments found within VS section could be redeposited from that group.

The youngest voluminous zircon population of $\sim 557$ Ma sets the maximum depositional age for most of the Sete Lagoas Formation and the Bambuí Group at around $560 \mathrm{Ma}$, which is supported by the recently found Ediacaran fauna. A concordia maximum depositional age of $593 \pm 1.7$ Ma was obtained for the basal sequence and no significant hiatus is expected across the sequence boundary. These data do no support the possibility of a major gap of about 130 Ma within the sedimentation of this unit after the basin drowning that ended the basal sequence. If there is such gap, it is positioned between the lowermost cap carbonates dated in $740 \pm 22 \mathrm{Ma}$ (Babinski et al., 2007) with very negative $\delta^{13} \mathrm{C}$ values and the carbonates with $\delta^{13} \mathrm{C}$ values around $0 \%$.

Our $\mathrm{U}-\mathrm{Pb}$ ages on detrital zircons suggest that the sedimentation of most of the Bambuí Group (at least in the eastern portion of the basin) started at the late Ediacaran and occurred on a restricted type basin, after the closure of the Adamastor Ocean and the build-up of the Araçuaí-West Congo Orogen to the east of the São Francisco Craton. The marine units were probably deposited on a restricted sea that did not homogenize its isotopic composition with the contemporaneous global ocean. This hypothesis is supported by the discrepancy between the ${ }^{87} \mathrm{Sr} /{ }^{86} \mathrm{Sr}$ ratios obtained for the Sete Lagoas Formation carbonates $(\sim 0.7075)$ and those expected for the late Ediacaran (>0.7080). Such discrepancy is also reported for other Ediacaran units worldwide. Therefore, extreme caution is required for global correlations and $\mathrm{Sr}$ "blind dating" of Ediacaran-Cambrian carbonate successions deposited on epicontinental seas.

\section{Acknowledgements}

The authors would like to thank the staff of the Geochronological Research Center of University of São Paulo for all the support given on the data acquirement. We also thank the Geotectonics and Regional Mapping Laboratory of the Federal University of Minas Gerais for the logistics and field work support, and two anonymous reviewers that greatly contributed to improve this work. This project was financed by FAPESP (05/58688).

\section{References}

Alkmim, F.F., Marshak, S., Pedrosa-Soares, A.C., Peres, G.G., Cruz, S.C., Whittington, A. 2006. Kinematic evolution of the Araçuaí-West Congo orogen in Brazil and Africa: nutcracker tectonics during the Neoproterozoic assembly of Gondwana. Precambrian Research 149, 43-63.

Alkmin, F.F., Martins-Neto, M.A., 2012. Proterozoic first-order sedimentary sequences of the São Francisco craton, eastern Brazil. Marine and Petroleum Geology 33 (1), 127-139.

Alvarenga, C.J.S., Santos, R.V., Dantas, E.L., 2004. C-O-Sr isotopic stratigraphy of cap carbonates overlying Marinoan-age glacial diamictites in the Paraguay Belt, Brazil. Precambrian Research 131, 1-21.

Alvarenga, C.J.S., Della Giustina, M.E.S., Silva, N.G.C., Santos, R.V.S., Gioia, S.M.C.L. Guimarães, E.M., Dardenne, M.A., Sial, A.N., Ferreira, V.P., 2007. Variações dos isótopos de C e Sr em carbonatos pré e pós-glaciação Jequitaí (Esturtiano) na região de Bezerra-Formosa, Goiás. Revista Brasileira de Geociencias 37 (4), 147-155.

Alvarenga, C.J.S., Dardenne, M.A., Santos, R.V., Brod, E.R., Gioia, S.M.C.L., Sial, A.N., Dantas, E.L., Ferreira, V.P., 2008. Isotope stratigraphy of Neoproterozoic cap carbonates in the Araras Group, Brazil. Gondwana Research 13, 469-479.

Azmy, K., Veizer, J., Misi, A. Oliveira, T.F., Sanches, A.L., Dardenne, M.A., 2001. Dolomitization and isotope stratigraphy of the Vazante Formation, São Francisco Basin, Brazil. Precambrian Research 112 (3-4), 303-329.

Babinski, M., Vieira, L.C., Trindade, R.I.F., 2007. Direct dating of Sete Lagoas cap carbonate (Bambuí Group, Brazil) and implications for the Neoproterozoic glacial events. Terra Nova 19, 401-406.

Babinski, M., Pedrosa-Soares, A.C., Trindade, R.I.F., Martins, M., Noce, C.M., Liu, D., 2012 Neoproterozoic glacial deposits from the Araçuaí orogen, Brazil: age, provenance 
and correlations with the São Francisco craton and West Congo belt. Gondwana Research 21, 451-465.

Boggiani, P.C., 1998. Análise estratigráfica da Bacia Corumbá (Neoproterozoico) - Mato Grosso do Sul. (PhD thesis) Universidade de São Paulo, Instituto de Geociências, (181 pp.).

Boggiani, P.C., Gaucher, C., Sial, A.N., Babinski, M., Simon, C.M., Riccomini, C., Ferreira, V.P., Fairchild, T.R., 2010. Chemostratigraphy of the Tamengo Formation (Corumbá Group, Brazil): a contribution to the calibration of the Ediacaran carbon-isotope curve. Precambrian Research 182 (4), 382-401.

Brand, U., Veizer, J., 1980. Chemical diagenesis of a multicomponent carbonate system-1: trace elements. Journal of Sedimentary Petrology 50, 1219-1236.

Brito-Neves, B.B., Campos-Neto, M.C., Fuck, R.A., 1999. From Rodínia to Western Gondwana: an approach to the Brasiliano-Pan African Cycle and orogenic collage. Episodes 22, 155-166.

Buchwaldt, R., Toulkeridis, T., Babinski, M., Santos, R., Noce, C.M., Martins-Neto, M.A Hercos, C.M., 1999. Age determination and age-related provenance analysis of the Proterozoic glaciation event in central-eastern Brazil. South American Symposium on Isotope Geology, 2, Cordoba, Argentina, Actas, pp. 387-390.

Cawood, P.A., Hawkesworth, C.J., Dhuime, B., 2012. Detrital zircon and tectonic record. Geology 40, 875-878.

Caxito, F.A., Halverson, G.P., Uhlein, A., Stevensson, R., Dias, T.G., Uhlein, G.J., 2012. Marinoan glaciation in east Central Brazil. Precambrian Research 200-203, 38-58.

Chemale, F., Dussin, I.A., Alkmim, F.F., Martins, M.S., Queiroga, G., Armstrong, R., Santos, M.N. 2012. Unravelling a Proterozoic basin history through detrital zircon geochronology: the case of the Espinhaço Supergroup, Minas Gerais, Brazil. Gondwana Research 22 (1), 200-206.

Coelho, J.C.C., Martins-Neto, M.A., Marinho, M.S., 2008. Estilos estruturais e evolução tectônica da porcão mineira da bacia proterozóica do São Francisco. Revista Brasileira de Geociencias 38 (2), 149-165.

Condon, D., Zhu, M., Bowring, S., Wang, W., Yang, A., Jin, Y., 2005. U-Pb ages from the Neoproterozoic Doushantuo Formation, China. Science 308, 95-98.

Cordani, U.G., Brito-Neves, B.B., D'agrella-Filho, M.S., Trindade, R.I.F., 2003. Tearing-up Rodinia: the Neoproterozoic paleogeography of South American cratonic fragments. Terra Nova 15, 343-349.

Dardenne, M.A., 1978. Síntese sobre a estratigrafia do Grupo Bambuí no Brasil Central. SBG, Congresso Brasileiro de Geolologia, 30, Recife, Brazil. Anais. v. 2, pp. 597-610.

Dardenne, M.A., 2000. The Brasília fold belt. In: Cordani, U.G., Milani, E.J., Thomaz-Filho, A Campos, D.A. (Eds.), Tectonic Evolution of South America. 31st International Geological Congress, Rio de Janeiro, pp. 231-263.

Derry, L.A., 2010. A burial diagenesis origin for the Ediacaran Shuram-Wonoka carbon isotope anomaly. Earth and Planetary Science Letters 294, 152-162.

Derry, L.A., Kaufman, A.J., Jacobsen, S.B., 1992. Sedimentary cycling and environmenta change in the Late Proterozoic: evidence from stable and radiogenic isotopes. Geochimica et Cosmochimica Acta 56, 1317-1329.

Elhlou, S., Belousova, E., Griffin, W.L., Pearson, N.J., O'Reilly, S.Y., 2006. Trace element and isotopic composition of GJ-red zircon standard by laser ablation. Geochimica et Cosmochimica Acta 70 (18), A158.

Fölling, P.G., Frimmel, H.E., 2002. Chemostratigraphic correlation of carbonate successions in the Gariep and Saldania Belts, Namibia and South Africa. Basin Research 14, 69-88.

Frimmel, H.E., 2009. Trace element distribution in Neoproterozoic carbonates as palaeoenvironmental indicator. Chemical Geology 258, 338-353.

Frimmel, H.E., 2010. On the reliability of stable carbon isotopes for Neoproterozoic chemostratigraphic correlation. Precambrian Research 182 (4), 239-253.

Gaillardet, J., Dupre, B., Allegre, C.J., Négrell, P., 1997. Chemical and physical denudation in the Amazon River Basin. Chemical Geology 142 (3-4), 141-173.

Gaucher, C., Sial, A.N., Blanco, G., Sprechmann, P., 2004. Chemostratigraphy of the Lower Arroyo del Soldado Group (Vendian, Uruguay) and paleoclimatic implications. Gondwana Research 7 (3), 715-730.

Goldstein, S.J., Jacobsen, S.B., 1987. The Nd and Sr isotopic systematic of river-water dissolved material: implications for the sources of $\mathrm{Nd}$ and $\mathrm{Sr}$ in seawater. Chemical Geology: Isotope Geoscience Section 66 (3-4), 245-272.

Grotzinger, J.P., Knoll, A.H., 1995. Anomalous carbonate precipitates: is the Precambrian the key to the Permian? Palaios 10, 578-596.

Grotzinger, J.P., Waters, W.A., Knoll, A.H., 2000. Calcified metazoans in thrombolitestromatolite reefs of the terminal Proterozoic Nama Group, Namibia. Paleobiology 26 (3), 334-359.

Halverson, G.P., Dudás, F.O., Maloof, A.C., Bowring, S.A., 2007. Evolution of the ${ }^{87} \mathrm{Sr} /{ }^{86} \mathrm{Sr}$ composition of Neoproterozoic seawater. Palaeogeography, Palaeoclimatology, Palaeoecology 256 (3-4), 103-129.

Halverson, G.P., Wade, B.P., Hurtgen, M.T., Barovich, K.M., 2010. Neoproterozoic chemostratigraphy. Precambrian Research 182, 337-350.

Heilbron, M., Tupinambá, M., Valeriano, C.M., Armstrong, R., Siva, L.G.E., Melo, R.S. Simonetti, A., Pedrosa-Soares, A.C., Machado, N., 2013. The Serra Bolívia Complex: the record of a new Neoproterozoic arc-related unit at Ribeira Belt. Precambrian Research 238, 158-175.

Hoffman, P.F., Schrag, D.P., 2002. The Snowball Earth hypothesis: testing the limits of global change. Terra Nova 14, 129-155.

Iyer, S.S., Babinski, M., Krouse, H.L., Chemale, F., 1995. Highly ${ }^{13} \mathrm{C}$ enriched carbonate and organic matter in the Neoproterozoic sediments of the Bambuí Group, Brazil. Precambrian Research 73, 271-282.

Jacobsen, S.B., Kaufman, A.J., 1999. The Sr, C and O isotopic evolution of Neoproterozoic seawater. Chemical Geology 161, 37-57.

Jones, C.E., Jenkyns, 2001. Seawater strontium isotopes, oceanic anoxic events, and seafloor hydrothermal activity in the Jurassic and Cretaceous. American Journal of Science 301, 112-149.
Karfunkel, J., Hoppe, A., 1988. Late Precambrian glaciation in central-eastern Brazil: synthesis and model. Palaeogeography Palaeoclimatology Palaeoecology 65, $1-21$.

Kennedy, M.J., 1996. Stratigraphy, sedimentology, and isotope geochemistry of Australian Neoproterozoic postglacial cap dolostones: deglaciation, $\delta^{13} \mathrm{C}$ excursions, and carbonate precipitation. Journal of Sedimentology Research 66, 1050-1064.

Krabbenhoft, A., Eisenhauer, A., Böhm, F., Vollstaedt, H., Fietzke, J., Liebetrau, V., Augustin, N., Peucker-Ehrenbrink, B., Müller, M.N., Horn, C., Hansen, B.T., Nolte, N., Wallmann, K., 2010. Constraining the marine strontium budget with natural strontium isotope fractionantions (87Sr/86Sr*, d88/86Sr) of carbonates, hydrothermal solutions and river waters. Geochimica et Cosmochimica Acta 74 (14), 4097-4109.

Kuchenbecker, M., 2011. Quimioestratigrafia e proveniência sedimentar da porção basal do Grupo Bambuí em Arcos (MG). (Masters Dissertation) Instituto de Geociências da Universidade Federal de Minas Gerais, Belo Horizonte, (91 pp.).

Kuchenbecker, M., Babinski, M., Pedrosa-Soares, A.C., Costa, R.D., Lopes-Silva, L., Pimenta, F., 2013. Proveniência e análise sedimentar da porção basal do Grupo Bambuí em Arcos (MG). Geologia USP Série Científica 13, 49-61.

Kusnetsov, A.B., Semikhatov, M.A., Gorokhov, I.M., 2012. The Sr isotope composition of world ocean, marginal and inland seas: implication for the $\mathrm{Sr}$ isotope stratigraphy. Stratigraphy and Geological Correlation 20 (6), 501-515.

Kusnetsov, A.B., Ovchinnikova, G.V., Gorokhov, I.M., Letnikova, E.F., Kaunova, O.K., Konstantinova, G.V., 2013. Age constraints on the Neoproterozoica Baikal Group, from combined $\mathrm{Sr}$ isotopes and $\mathrm{Pb}-\mathrm{Pb}$ dating of carbonates from Baikal type section, southeastern Siberia. Journal of Asian Earth Sciences 62, 51-66.

Li, Z.X., Bogdanova, S.V., Collins, A.S., Davidson, A., De Waele, B., Fitzsimons, I.C.W., Fuck, R.A., Gladkochub, D.P., Jacobs, J., Ernst, R.E., Karlstrom, K.E., Lu, S., Natapov, L.M., Pease, V. Pisarevsky, S.A., Thrane, K., Vernikovsky, V., 2008. Assembly, configuration, and break-up history of Rodinia: a synthesis. Precambrian Research 160, 179-210.

Li, D., Ling, H.F. Shields-Zhou, G.A., Chen, X., Cremonese, L., Och, L., Thirwall, M., Manning, C.J., 2013. Carbon and strontium isotope evolution of seawater across the EdiacaranCambrian transition: evidence from Xiaotan section, NE Yunnan, South China. Precambrian Research 225, 128-147.

Martins-Neto, M.A., Hercos, C.M., 2002. Sedimentation and tectonic setting of Early Neoproterozoic glacial deposits in southeastern Brazil. In: Altermann, W., Corcoran, P.L. (Eds.), Precambrian sedimentary environments: a modern approach to ancient depositional systems. International Association of Sedimentologists, Special Publications. 33, pp. 383-403.

Martins-Neto, M.A., Pedrosa-Soares, A.C., Lima, S.A.A., 2001. Tectono-sedimentary evolution of sedimentary basis from Late Paleoproterozoic to Late Neoproterozoic in the São Francisco craton and Araçuaí fold belt, eastern Brazil. Sedimentary Geology 142, 343-370.

Melezhik, V.A., Gorokhov, I.M., Kuznetsov, A.B., Fallick, A.E., 2001. Chemostratigraphy of Neoproterozoic carbonates: implications for "blind dating". Terra Nova 13,1-11.

Misi, A., Veizer, J., 1998. Neoproterozoic carbonate sequences of the Una Group, Irece Basin, Brazil: chemostratigraphy, age and correlations. Precambrian Research 89, 87-100.

Misi, A., Kaufman, A.J., Veizer, J., Powis, K., Azmy, K., Boggiani, P.C., Gaucher, C., Teixeira, J.B.G., Sanchez, A.L., Iyer, S.S.S., 2007. Chemostratigraphic correlation of Neoproterozoic successions in South America. Chemical Geology 237, 143-167.

Ohno, T., Komiya, T., Ueno, Y., Hirata, T., Maruyama, S., 2008. Determination of ${ }^{88} \mathrm{Sr} /{ }^{86} \mathrm{Sr}$ mass-dependent isotopic fractionation and radiogenic isotope variation of ${ }^{87} \mathrm{Sr} /{ }^{86} \mathrm{Sr}$ in the Neoproterozoic Doushantuo Formation. Gondwana Research 14, 126-133.

Ovchinnikova, G.V., Kusnetsov, A.B., Vasil'eva, I.M., Gorokhov, I.M., Letnikova, E.F., Gorokhovskii, B.M., 2012. U-Pb age and $\mathrm{Sr}$ isotope signature of cap limestones from the Neoproterozoic Tsagaan Oloom Formation, Dzabkhan River Basin, Western Mongolia. Geological Correlation 20 (06), 516-527.

Palmer, M.R., Edmond, J.M., 1989. The strontium isotope budget of the modern ocean. Earth and Planetary Science Letters 92, 11-26.

Palmer, M.R., Edmond, J.M., 1992. Controls over the strontium isotope composition of river water. Geochimica et Cosmochimica Acta 56, 2099-2111.

Pedrosa-Soares, A.C., Cordani, U.G., Nutman, A., 2000. Constraining the age of Neoproterozoic Glaciation in Eastern Brazil: first U-Pb (SHRIMP) data for detrital zircons. Revista Brasileira de Geociencias 30, 58-61.

Pedrosa-Soares, A.C., Alkmim, F.F., Tack, L, Noce, C.M., Babinski, M., Silva, L.C, MartinsNeto, M., 2008. Similarities and differences between the Brazilian and African counterparts of the Neoproterozoic Araçuaí-West Congo Orogen. In: Pankhurst, J.R., Trouw, R.A.J., Brito-Neves, B.B., De Wit, M.J. (Eds.), West Gondwana: Pre-Cenozoic Correlations Across the South Atlantic Region. Geological Society of London Special Publications. 294, pp. 153-172.

Pedrosa-Soares, A.C., Babinski, M., Noce, C., Martins, M., Queiroga, G., Vilela, F., 2011a. The Neoproterozoic Macaúbas Group (Araçuá orogen, SE Brazil). In: Arnaud, E. Halverson, G.P., Shields-Zhou, G. (Eds.), The Geological Record of Neoproterozoic Glaciations. Geological Society, London, Memoirs. 36, pp. 523-534.

Pedrosa-Soares, A.C., De Campos, C.P., Noce, C., Silva, L.C., Novo, T., Roncato, J., Medeiros, S., Castañeda, C., Queiroga, G., Dantas, E., Dussin, I., Alkmim, F.F. 2011b. Late Neoproterozoic-Cambrian granitic magmatism in the Araçuaí orogen (Brazil), the Eastern Brazilian Pegmatite Province and related mineral resources. Geological Society of London, Special Publications 350, 25-51.

Peixoto, E., Pedrosa-Soares, A.C., Alkmim, F.F., Dussin, I.A., 2015. A suture-related accretionary wedge formed in the Neoproterozoic Araçuaí orogen (SE Brazil) during Western Gondwanaland assembly. Gondwana Research 27 (2), 878-896.

Pimentel, M.M., Fuck, R.A., Botelho, N.F., 1999. Granites and the geodynamic history of the Neoproterozoic Brasilia belt, Central Brazil: a review. Lithos 46 (3), 463-483.

Pimentel, M.M., Dardenne, M.A., Fuck, R.A., Viana, M.G., Junges, S.L., Fischel, D.P., Seer, H.J., Dantas, E.L., 2001. Nd isotopes and the provenance of detrital sediments of the 
neoproterozoic Brasília belt, central Brazil. Journal of South American Earth Sciences 14 (6), 571-585

Pimentel, M.M., Rodrigues, J.B., Della Giustina, M.E.S., Junges, S., Matteini, M., Armstrong, R., 2011. The tectonic evolution of the Neoproterozoic Brasília Belt, central Brazil, based on SHRIMP and LA-ICPMS U-Pb sedimentary provenance data: a review. Journal of South America Earth Sciences 31, 345-357.

Projeto Vida. CPRM - Serviço Geológico do Brasil. 2003. Mapeamento Geológico Região de Sete Lagoas, Pedro Leopoldo, Matozinhos, Lagoa Santa, Vespasiano, Capim Branco, Prudente de Morais, Confins e Funilândia. Mapa Geológico, scale 1:50,000.

Queiroga, G.N., Pedrosa-Soares, A.C., Noce, C.M., Alkmim, F.F., Pimentel, M.M., Dantas, E., Martins, M., Castañeda, C., Suita, M.T.F., Prichard, H., 2007. Age of the Ribeirão da Folha ophiolite: the U-Pb zircon (LA-ICPMS) dating of a plagiogranite. Geonomos 15 (1), 61-65.

Rocha-Campos, A.C., Hasui, Y., 1981. Tillites of the Macaúbas Group (Proterozoic) in central Minas Gerais and southern Bahia, Brazil. In: Hambrey, M.J., Harland, W.B. (Eds.), Earth's Pre-Pleistocene Glacial Record. Cambridge University Press, pp. 933-939.

Rodrigues, J.B., 2008. Proveniência de sedimentos dos grupos Canastra, Ibiá, Vazante e Bambuí - um estudo de zircões detríticos e Idades Modelo Sm-Nd. (PhD Thesis) Instituto de Geociências, Universidade de Brasília, Brasília, (128pp.).

Rodrigues, J.B., Pimentel, M.M., Buhn, B., Matteini, M., Dardenne, M.A., Alvarenga, C.J.S., Armstrong, R.A., 2012. Provenance of the Vazante Group: new U-Pb, Sm-Nd, Lu-Hf isotopic data and implications for the tectonic evolution of the Neoproterozoic Brasília Belt. Gondwana Research 21 (2-3), 439-450.

Santos, R.V., Alvarenga, C.J.S., Dardenne, M.A., Sial, A.N., Ferreira, V.P., 2000. Carbon and oxygen isotope profiles across Meso-Neoproterozoic limestones from central Brazil: Bambuí and Paranoá Groups. Precambrian Research 104, 107-122.

Santos, R.V., Alvarenga, C.J.S., Babinski, M., Ramos, M.L.S., Cukrov, N., Fonseca, M.A., Sial, A.N., Dardenne, M.A., Noce, C.M., 2004. Carbon isotopes of Mesoproterozoic-Neoproterozoic sequences from Southern São Francisco cráton and Araçuaí Belt, Brazil: paleogeographic implications. Journal of South American Earth Sciences 18, 27-39.

Sial, A.N., Dardenne, M.A., Misi, A., Pedreira, A.J., Gaucher, C., Ferreira, V.P., Silva Filho, M.A. Uhlein, A., Pedrosa-Soares, A.C., Santos, R.V., Egydio-Silva, M., Babinski, M., Alvarenga, C.J.S., Fairchild, T.R., Pimentel, M.M., 2009. Chapter 3 - The São Francisco Palaeocontinent. In: Gaucher, C., Sial, A.N., Halverson, G.P., Frimmel, H.E., (Org.). Developments in Precambrian Geology. 1 ed., London: Elsevier 16, 31-69.

Silva, L.C., Pedrosa-Soares, A.C., Teixeira, L.R., Armstrong, R., 2008. Tonian rift-related A-type continental plutonism in the Araçuaí Orogen, eastern Brazil: new evidence for the breakup stage of the São Francisco-Congo Paleocontinent. Gondwana Research 13, 527-537.

Silva-Tamayo, J.C., Nägler, T.F., Villa, I.M., Kyser, K., Vieira, L.C., Sial, A.N., Narbonne, G.M., James, N.P., 2010. Global Ca isotope variations in c. 0.7 Ga old post-glacial carbonate successions. Terra Nova 22, 188-194.

Tack, L., Wingate, M.T.D., Liégeois, J.P., Fernandez-Alonso, M., Deblond, A., 2001. Early Neoproterozoic magmatism (1000-910 Ma) of the Zadinian and Mayumbian Groups (Bas-Congo): onset of Rodinian rifting at the western edge of the Congo craton. Precambrian Research 110, 277-306.

Teixeira, W., Kamo, S.L., Arcanjo, J.B.A., 1997. U-Pb zircon and baddeleyite age and tectonic interpretation of the Itabuna alkaline suite, São Francisco Craton, Brazil. Journal of South America Earth Sciences 10 (1), 91-98.
Teixeira, W., Sabaté, P., Barbosa, J., Noce, C.M., Carneiro, M.A., 2000. Archean and Paleoproterozoic tectonic evolution of the São Francisco craton, Brazil. In: Cordani, U.G., Milani, E.J., Thomaz-Filho, A., Campos, D.A. (Eds.), Tectonic Evolution of South America. 31st International Geology Congress, Rio de Janeiro, pp. 101-137.

Tera, F., Wasserburg, G.J., 1972. U-Th-Pb systematics in three Apollo 14 basalts and the problem of initial Pb in lunar rocks. Earth Planetary Science Letters 14, 281-304.

Trindade, R.I.F., D'Agrella-Filho, M.S., Epof, I., Brito-Neves, B.B., 2006. Paleomagnetism of Early Cambrian Itabaiana mafic dikes (NE Brazil) and the final assembly of Gondwana. Earth and Planetary Science Letters 244, 361-377.

Tupinambá, M., Heilbron, M., Valeriano, C., Júnior, R.P., Diós, F.B., Machado, N., Silva, L.G.E. Almeida, J.C.H., 2012. Juvenile contribution of the Neoproterozoic Rio Negro magamatic arc (Ribeira Belt, Brazil): Implications for Western Gondwana amalgamation. Gondwana Research 21 (2-3), 422-438.

Uhlein, A., Trompette, R., Alvarenga, C., 1999. Neoproterozoic glacial and gravitational sedimentation on a continental rifted margin: the Jequitaí-Macaúbas sequence (Minas Gerais, Brazil). Journal of South American Earth Sciences 12, 435-451.

Valeriano, C.M., Machado, N., Simonetti, A., Valladares, C.S., Seer, H.J., Simões, L.S.A., 2004 $\mathrm{U}-\mathrm{Pb}$ geochronology of Southern Brasília belt (SE-Brazil): sedimentary provenance, Neoproterozoic orogeny and assembly of West Gondwana. Precambrian Research 130, 27-55.

Valeriano, C.M., Pimentel, M.M., Heilbrin, M., Almeida, J.C.H., Trouw, R.A.J., 2008. Tectonic evolution of the Brasília Belt, Central Brazil, and early assembly of Gondwana. In: Pankhurst, R.J., Trouw, R.A.J., Brito-Neves, B.B., De Wit, M.J. (Eds.), West Gondwana: Pre-Cenozoic Correlations Across the South Atlantic Region. Geological Society London, Special Publications. 294, pp. 197-210.

Valladares, C.S., Machado, N., Heilbron, M., Gauthier, G., 2004. Ages of detrital zircon from siliciclastic successions south of the São Francisco Craton, Brazil: implications for the evolution of proterozoic basins. Gondwana Research 7 (4), 913-921.

Veizer, J., Compston, W. Clauer, N., Schidlowski, M. $1983{ }^{87} \mathrm{Sr} /{ }^{86} \mathrm{Sr}$ in Late Proterozoic carbonates: evidence for a mantle event at 900 Ma ago. Geochimica et Cosmochimica Acta 47, 295-302.

Veizer, J., Hoefs, J., Ridler, R.H., Jensen, L.S., Lowe, D.R., 1989. Geochemistry of Precambrian carbonates: I. Archean hydrothermal systems. Geochimica et Cosmochimica Acta 53, $845-857$.

Vieira, L.C., Trindade, R.I.F., Nogueira, A.C.R., Ader, M., 2007. Identification of a Sturtian cap carbonate in the Neoproterozoic Sete Lagoas carbonate platform, Bambuí Group, Brazil. Comptes Rendus Geosciences 339, 240-258.

Walter, M.R., Veevers, J.J., Calver, C.R., Gerjan, P., Hill, A.C., 2000. Dating the 840-544 Ma Neoproterozoic interval by isotopes of strontium, carbon, and sulfur in seawater, and some interpretative models. Precambrian Research 100, 371-433.

Warren, L.V., Quaglio, F., Riccomini, C., Simões, M.G., Poiré, D.G., Strikis, N.M., Anelli, L.E. Strikis, P.C., 2014. The puzzle assembled: Ediacaran guide fossil Cloudina reveals an old proto-Gondwana seaway. Geology http://dx.doi.org/10.1130/G35304.1.

Zhao, Y., Zheng, Y., Chen, F., 2009. Trace element and strontium isotope on sedimentary environment of Ediacaran carbonates in southern Anhui, South China. Chemical Geology 265, 345-362. 